Illinois State University

ISU ReD: Research and eData

Theses and Dissertations

2-12-2015

\title{
Functional Expression and Characterization of a Truncated Candida antarctica Lipase B in Yeast
}

Samantha Robinson

Illinois State University, smrobin86@gmail.com

Follow this and additional works at: https://ir.library.illinoisstate.edu/etd

Part of the Biochemistry Commons, and the Chemistry Commons

\section{Recommended Citation}

Robinson, Samantha, "Functional Expression and Characterization of a Truncated Candida antarctica Lipase B in Yeast" (2015). Theses and Dissertations. 309.

https://ir.library.illinoisstate.edu/etd/309

This Thesis is brought to you for free and open access by ISU ReD: Research and eData. It has been accepted for inclusion in Theses and Dissertations by an authorized administrator of ISU ReD: Research and eData. For more information, please contact ISUReD@ilstu.edu. 


\title{
FUNCTIONAL EXPRESSION AND CHARACTERIZATION OF A TRUNCATED
}

\section{CANDIDA ANTARCTICA LIPASE B IN YEAST}

\author{
Samantha M. Robinson
}

77 Pages

May 2015

Candida antarctica lipase B (CalB) is an enzyme capable of hydrolyzing ester bonds in a lipid-water interface with potential to become a useful biocatalyst for production of biodiesel fuel. Enzymatically catalyzing the transesterification of triacylglycerols to produce fatty acid alkyl esters (biodiesel) is an environmentally cleaner alternative to the current process which utilizes chemical reagents as catalysts. However, the high cost of enzymes is the main hurdle preventing the implementation of this process in industry. Optimization and development of strains to express highly active, stable, and large quantities of these biocatalysts is essential for inexpensive production of biodiesel. Additionally, lipase enzymes can be immobilized onto a resin, eliminating the need to recover the catalyst from the product and allowing multiple cycle use. An integrated biorefinery combining starch ethanol and cellulosic ethanol production in one location may become cost-effective if biodiesel is produced as a co-product in a single-step column transesterification of ethanol and corn oil catalyzed by these resinbound, low-cost lipases expressed in a recombinant yeast strain capable of cellulosic ethanol production. 
The focus of this research work was to determine if a truncated version of CalB (Hughes et al. 2011) was functionally expressed in the Saccharomyces cerevisiae yeast strain PJ69-4 and exhibited comparable activity to the wild-type enzyme, commercially known as Novozym 435. The truncated CalB was immobilized on Sepabeads® resin and assayed for production of fatty acid ethyl and butyl esters from crude corn oil or refined soybean oil triacylglycerols and cellulosic ethanol or n-butanol. Different parameters, including alcohol to oil ratios and coupling with an ionic catalytic resin were also assessed in some trials. Additionally, kinetic analysis of the truncated CalB was performed using the methods of Blank et al. (2006) and Martinelle et al. (1995) to determine the maximal rate or velocity of reaction, $\mathrm{V}_{\max }$, and the Michaelis-Menten constant, $\mathrm{K}_{\mathrm{m}}$, and comparing these values to those measured from the wild-type CalB enzyme.

This research showed that the resin-bound truncated CalB catalyzed production of ethyl and butyl esters, which was determined by GC analysis, from crude corn oil and refined soybean oil. The addition of an ionic catalytic resin with the resin-bound truncated CalB, as well as varying the ratios of alcohol to oil, was shown to positively affect yield of biodiesel in some instances. Kinetic analysis determined that the truncated CalB was comparable, but slightly less active, catalytically than the wild-type CalB enzyme. 
FUNCTIONAL EXPRESSION AND CHARACTERIZATION OF A TRUNCATED

CANDIDA ANTARCTICA LIPASE B IN YEAST

SAMANTHA M. ROBINSON

A Thesis Submitted in Partial Fulfillment of the Requirements for the Degree of

MASTER OF SCIENCE

Department of Chemistry

ILLINOIS STATE UNIVERSITY

2015 
(C) 2015 Samantha M. Robinson 
FUNCTIONAL EXPRESSION AND CHARACTERIZATION OF A TRUNCATED CANDIDA ANTARCTICA LIPASE B IN YEAST

SAMANTHA M. ROBINSON

COMMITTEE MEMBERS:

Jon A. Friesen, Co-Chair

Stephen R. Hughes, Co-Chair

Marjorie A. Jones

Gregory M. Ferrence 


\section{ACKNOWLEDGMENTS}

Firstly, I would like to thank Dr. Ken Tasaki and Mitsubishi Chemical Corporation, as this project would not have been possible if it were not for their generous funding, allowing me to have the opportunity and privilege to do part of my graduate research at the United States Department of Agriculture NCAUR facility. Secondly, I would like to thank my research advisor, Dr. Jon Friesen, for offering his expertise in biochemistry and enabling me to become a better scientist. I am truly thankful for the opportunity to work in his lab and learn from him. I would like to thank Dr. Marjorie Jones, Dr. Gregory Ferrence, and the rest of the Illinois State University Chemistry Department professors, staff, and graduate students, for all the help, support, and valuable education I have received over the course of this journey. I would like to give special thanks to Dr. Stephen Hughes, for mentoring and assisting me with this research, and allowing me to work in his laboratory at the USDA. I would also like to thank to Dr. Bryan Moser, Dr. Ken Doll, Dr. Ken Bischoff, Dr. Nasib Qureshi, and their respective research groups at the USDA for their collaboration and insight on this project. And finally, I would like to thank my family, friends, and especially my partner, Michael, for giving me the continuous support and encouragement needed to complete this project.

S.M.R. 


\section{CONTENTS}

Page

ACKNOWLEDGMENTS $\quad$ i

CONTENTS

TABLES $\quad$ V

FIGURES $\quad$ vi

CHAPTER

I. INTRODUCTION 1

Candida antarctica Lipase B $\quad 1$

A Potential Alternative in Industrial Biodiesel Production 3

Implementation of an Enzymatic Biodiesel Process 7

Resin-bound Enzyme Immobilization $\quad 8$

$\begin{array}{ll}\text { Purpose of Thesis } & 9\end{array}$

II. MATERIALS AND METHODS 11

Chemicals $\quad 11$

$\begin{array}{ll}\text { Supplies } & 12\end{array}$

$\begin{array}{ll}\text { Equipment } & 13\end{array}$

Selective Medium Plate Preparation 13

Preparation of Liquid Media 14

Preparation of Liquid Cultures $\quad 15$

$\begin{array}{ll}\text { Cell Lysis and Protein Extraction } & 16\end{array}$

Method Utilized at NCAUR, USDA 16

Method Utilized at Illinois State University 16

$\begin{array}{ll}\text { Protein Solubilization with Detergents } & 17\end{array}$

$\begin{array}{ll}\text { Protein Isolation and Purification } & 18\end{array}$

Method Utilized at NCAUR, USDA 18

Method Utilized at Illinois State University 18 
BioRad Protein Assay 19

Binding Enzyme to Resin 19

Fatty Acid Alkyl Ester Production 20

Analysis by Gas Chromatography 21

$\begin{array}{ll}\text { SDS-PAGE } & 21\end{array}$

Method Utilized at NCAUR, USDA 22

Method Utilized at Illinois State University 22

Coomassie Protein Stain $\quad 23$

Western Blot Analysis $\quad 23$

Densitometry 26

Enzyme Activity 26

III. RESULTS AND DISCUSSION 29

Expression of Truncated CalB in Growth Medium 29

Fatty Acid Ethyl Ester Production by Resin-bound Truncated CalB 31

Fatty Acid Ethyl Ester Production from Ethanol and Corn Oil by Resin-bound Truncated CalB

in Conjunction with an Ionic Catalytic Resin

Fatty Acid Ethyl Ester Production Catalyzed by

Resin-bound Truncated CalB with Various

Ratios of Ethanol to Corn Oil 35

Fatty Acid Alkyl Ester Production Using Resin-bound

Truncated CalB with Ethanol or n-Butanol 37

Protein Analysis of Truncated CalB 39

SDS-PAGE Analysis of Truncated CalB 41

Effects of Addition of a Reducing Agent 44

Effects of Addition of Protein Detergents 46

Effect of Increased Pressure During Cell Lysis 51

Determination of Kinetic Activity 53

IV. CONCLUSIONS AND FUTURE WORK 58

Expression of the Truncated CalB $\quad 58$

Biodiesel Assays $\quad 59$

Purification and Isolation of Truncated CalB 62

Kinetic Activity of Truncated CalB 65

Future Work $\quad 67$

$\begin{array}{lr}\text { REFERENCES } & 69\end{array}$

APPENDIX A: Protein Solubilizing Detergents 72

APPENDIX B: Bradford Protein Assay 73 
APPENDIX C: Biodiesel Assays

APPENDIX D: Kinetic Enzyme Assays 


\section{TABLES}

Table $\quad$ Page

1. Summary of Kinetic Constants Determined for Truncated and Full-length CalB 


\section{FIGURES}

Figure $\quad$ Page

1. Rasmol 3D rendering of Candida antarctica lipase B active site. 2

2. Transesterification reaction. 4

3. Saponification reaction. $\quad 4$

4. Lipase catalytic cycle for fatty acid alkyl ester (biodiesel) production. The cycle of reactions (i-iv) is repeated until all of the acylglycerols (TAG, DAG, MAG) are converted to fatty acid alkyl esters and a glycerol is formed.

5. Schematic of lipase enzyme immobilization to a resin containing an epoxy functional group in two steps; enzyme adsorption to the resin hydrophobically (i), covalent linkage of an enzyme amino group to the epoxy functional group (ii).

6. Western blot analysis of six CalB variants in PJ69-4 yeast cultures when grown in glucose (YPD) medium (left), and when switched to galactose (YPG) medium (right).

7. Fatty acid ethyl ester (EE) production per milligram of enzyme from corn oil (CO) or soybean oil (SBO) using resin-bound truncated CalB or Novozym 435 measured by gas chromatography. Data are single point determinations.

8. C16 and C18 fatty acid ethyl ester production from corn oil (CO) versus soybean oil (SBO) using resin-bound truncated CalB compared to commercial lipase, Novozym 435. Data are the calculated averages of three determinations. Error bars represent standard deviation.

9. Addition of an ionic catalytic resin step prior to the truncated CalB resin. Data are the calculated averages of three determinations. Error bars represent standard deviation. 
10. Production of C16 and C18 fatty acid ethyl esters using 5:1, 15:1, and 30:1 (v/v) ratios of ethanol to corn oil. Data are the calculated averages of three determinations. Error bars represent standard deviation.

11. Fatty acid alkyl ester production using resin-bound truncated CalB with $5: 1(\mathrm{v} / \mathrm{v})$ ratio of ethanol or $\mathrm{n}$-butanol to corn oil. Data are single point determinations.

12. Bradford Assay BSA standard curve of detected absorbance at $595 \mathrm{~nm}$.

13. Amount of protein eluted $(\mathrm{mg})$ in each fraction collected from the TALON® resin column using $200 \mathrm{mM}$ imidazole, $\mathrm{pH} 7.5$ buffer and collecting $1 \mathrm{~mL}$ per fraction.

14. Coomassie blue staining of the polyacrylamide gel containing the samples collected throughout the purification process.

15. Western blot of the samples collected throughout the protein purification process.

16. Coomassie blue staining of the purified samples prepared in SDS-PAGE loading buffer containing $2 \mathrm{X} \beta$-mercaptoethanol (BME) and $4 \mathrm{X}$ standard loading buffer.

17. Coomassie blue stained SDS-PAGE showing samples taken from truncated and full-length CalB lysate pellet resuspended in 1\% NP-40 in $50 \mathrm{mM}$ Tris, $100 \mathrm{mM} \mathrm{NaCl}$, pH 7.5 buffer.

18. Coomassie blue stain showing samples taken from truncated and fulllength CalB lysate pellet resuspended in 10\% NP-40 in $50 \mathrm{mM}$ Tris, $100 \mathrm{mM} \mathrm{NaCl}, \mathrm{pH} 7.5$ buffer.

19. Western blot of samples from full-length CalB lysate pellet resuspended in $10 \%$ Triton X-100 and 1\% OGP in $50 \mathrm{mM}$ Tris, $100 \mathrm{mM} \mathrm{NaCl}, \mathrm{pH} 7.5$ buffer.

20. Western blot of truncated CalB lysate pellet resuspended in $10 \%$ Triton $\mathrm{X}-100$ and 1\% OGP in $50 \mathrm{mM}$ Tris, $100 \mathrm{mM} \mathrm{NaCl}, \mathrm{pH} 7.5$ buffer.

21. Western blot of purification samples after yeast cell lysis at increased pressure of 30,000 psi. 
22. Michaelis-Menten plot for the substrate $\mathrm{p}-\mathrm{NPB}$ ranging from 40-1000 $\mu \mathrm{M}$ and the truncated CalB enzyme using the method of Blank et al. (2006).

23. Michaelis-Menten plot for the substrate $\mathrm{p}-\mathrm{NPB}$ ranging from 40-6000 $\mu \mathrm{M}$ and the truncated CalB enzyme using the method of Blank et al. (2006).

24. Michaelis-Menten plot for the substrate p-NPB ranging from 40-20000 $\mu \mathrm{M}$ and the truncated CalB enzyme using the method of Martinelle et al. (1995).

25. Michaelis-Menten plot for the substrate $\mathrm{p}-\mathrm{NPB}$ ranging from 40-20000 $\mu \mathrm{M}$ and the full-length CalB enzyme using the method of Martinelle et al. (1995). 


\section{CHAPTER I}

\section{INTRODUCTION}

\section{Candida antarctica Lipase B}

Lipases are a class of esterase enzymes that possess the capability of hydrolyzing ester bonds in a lipid-water interface. They perform essential roles in digestion, transport, and processing of dietary lipids such as triacylglycerols in most living organisms. One of the distinguishing characteristics of lipases in relation to other esterase enzymes is increased activity upon binding to a lipid surface, a process known as interfacial activation. This is believed to result in a conformational change of an amphiphilic peptide loop, commonly referred to as a "lid" that typically covers the active site (Overbeeke et al. 2000). The active site of a lipase is comprised of the four essential features of the serine hydrolase family of enzymes, which are the three-side-chain catalytic triad, the oxyanion hole, the specificity pocket, and the main chain substrate binding region (Branden and Tooze 1999). Esterases typically hydrolyze only water-soluble esters, but lipases are capable of cleaving ester bonds in water-insoluble triacylglycerols.

Candida antarctica lipase B (CalB), known commercially as Novozym 435, is a serine hydrolase lipase efficient in catalyzing transesterification of triacylglycerol with primary or secondary alcohols, producing glycerol and fatty acid alkyl esters. CalB is comprised of 317 amino acids with a molecular mass of $33 \mathrm{kDa}$ (Gotor-Fernandez et al. 
2006). X-ray structures have shown that it primarily consists of an $\alpha / \beta$-hydrolase fold represented by an eight-stranded, mostly parallel twisted $\beta$-sheet flanked by $\alpha$-helices on both sides (Uppenberg et al. 1994a). Unlike most lipases, CalB displays no interfacial activation and does not possess a typical lid domain over the active site (Martinelle et al. 1995; Blank et al. 2006). The active site consists of a catalytic triad, Asp187-His224Ser105, oriented from left to right, containing two hydrophobic channels above and below the triad (Figure 1). These two channels make up the two substrate-binding sites; the alcohol-binding pocket (specificity pocket) below the catalytic triad, and the acylbinding pocket (main chain substrate binding region) above it. Running almost parallel from the active site serine to the surface, they are barely separated by two hydrophobic side chains, Ile189 and Ile 285 . In all lipases, the active site serine acts as a nucleophile (similar to the serine proteinase design) and is capable of forming a tetrahedral intermediate upon interaction with an acyl carbonyl carbon (Uppenberg et al. 1995).

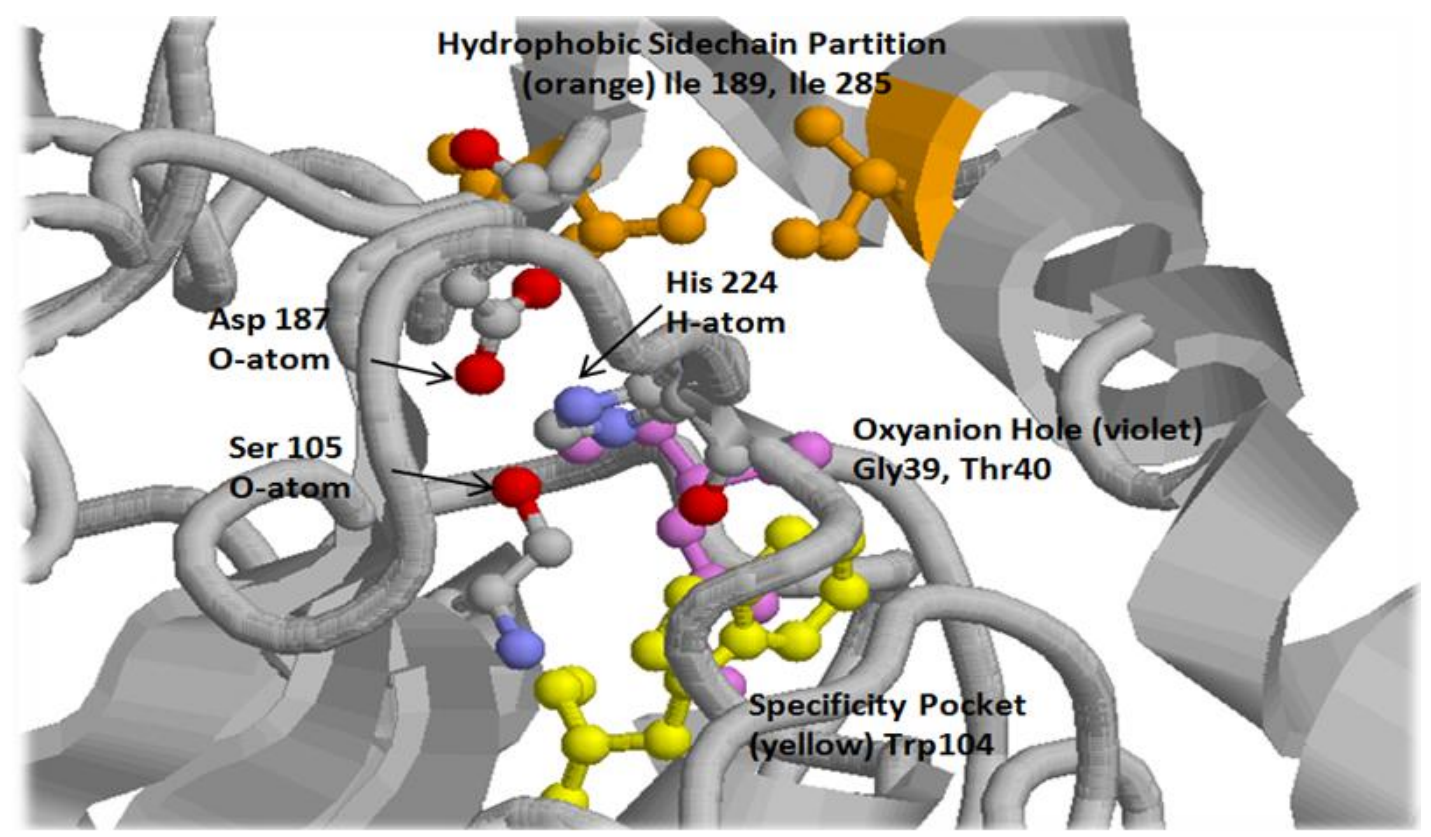

Figure 1. Rasmol 3D rendering of Candida antarctica lipase B active site. 
A distinctive characteristic of CalB is its high stereoselectivity towards secondary alcohols. Many substrate mapping procedures in the CalB active site have concluded that the stereoselectivity is higher when the substrate contains two substituents of varying size on the alcohol chiral carbon (Uppenberg et al. 1995). If there is a considerable difference in size between the substituents, namely if one is much larger than the other, an enantiomeric preference can be obtained. The alcohol-binding pocket of the active site is buried under a surface helix and is partially occupied by the side chain of Trp104. The limited space in this channel consequently forms a specificity pocket for the alcohol substrate. If there is a secondary alcohol present, the smaller substituent on the chiral carbon will be more likely to fit into the CalB active site channel.

\section{A Potential Alternative in Industrial Biodiesel Production}

CalB is becoming a popular biocatalyst in industrial applications, commonly used as an alternative for producing fatty acid alkyl esters needed for making biodiesel. The enzyme can catalyze the transesterification reaction needed to make fatty acid alkyl esters enzymatically instead of by means of additive chemical reagents.

Traditionally, biodiesel is produced by alkali-catalyzed transesterification of short-chain alcohols with oil or fat (triacylglycerols), yielding glycerol and the corresponding fatty acid alkyl esters used for biodiesel fuel (Figure 2). Catalysts typically used for this process are the strongly basic, alkali compounds sodium or potassium hydroxide, which are relatively inexpensive and give high levels of conversion in short reaction times (Fukuda et al. 2001). 


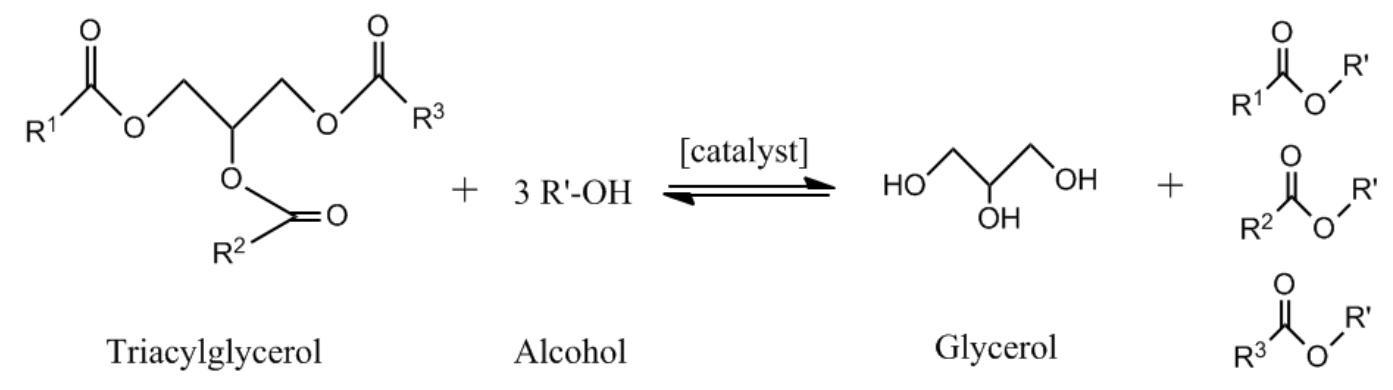

Fatty Acid Alkyl Esters (Biodiesel)

Figure 2. Transesterification reaction.

However, there are several drawbacks to using these chemical catalysts for producing biodiesel. These chemicals are not reusable, therefore they must constantly be replenished for continuous production of biodiesel. There is a high tendency for a saponification reaction to occur (Figure 3), where not only fatty acid alkyl esters are produced, but also fatty acid salts (crude soap), effectively lowering overall fatty acid alkyl ester yield and making the removal and purification of glycerol difficult. In order to prevent such product formation, refined oils with low free fatty acid content are needed, which cost more to process and as a result increase the overall cost of biodiesel production.

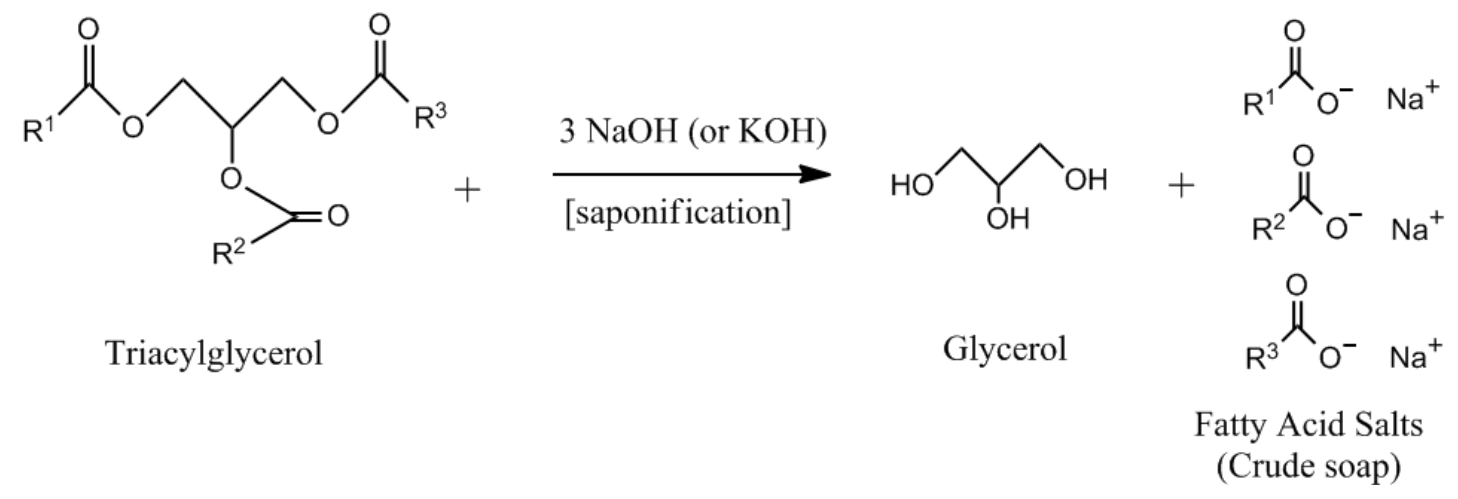

Figure 3. Saponification reaction. 
The process of enzymatic transesterification by using lipases as biocatalysts has become a very popular area of research in the past decade in efforts to overcome several of the drawbacks currently associated with traditional biodiesel production. The kinetic mechanism of a lipase follows the Ping-Pong Bi-Bi model, where two substrates yield two products as a result of the first substrate interacting with the enzyme to form one product and an enzyme-substrate complex, then the second substrate interacts with the latter forming the second product, reverting the enzyme to its free form (Al-Zuhair 2005). For a triglyceride substrate, this mechanism is repeated until triacylglycerol (TAG), diacylglycerol (DAG), and monoacylglycerol (MAG) are converted to the final fatty acid alkyl ester product. In order to complete all three cycles, a stoichiometric ratio of at least 3:1 of alcohol to oil must be used.

Lipase catalysis is rooted in the hydrogen bonding network in the core structure of the enzyme active site, the catalytic triad. This structure typically consists of a nucleophilic serine, a basic histidine, and an acidic aspartate residue. When the hydroxyl proton of the serine residue contributes to the hydrogen bonding network of the triad, the oxygen of the serine residue becomes more nucleophilic and attacks the $\mathrm{sp}^{2}$-hybridized carbonyl carbon of the acylglycerol substrate, making it $\mathrm{sp}^{3}$-hybridized (Rotticci et al. 2000). The first tetrahedral intermediate is formed when the histidine residue donates a proton to the resulting negative charge on the ester oxygen, stabilizing it (Figure 4, i). The negative charge of the oxyanion is then transferred to the ester oxygen, resulting in the cleavage of the ester bond and thus forming the acyl substrate-enzyme complex and the first product (Figure 4, ii). The second substrate, the alcohol, binds to the acyl substrate-enzyme complex, resulting in a second tetrahedral intermediate, where the 
histidine residue donates a proton to the serine residue oxygen, resulting in the cleaving of the ester bond to yield the second product (Figure 4, iii and iv)

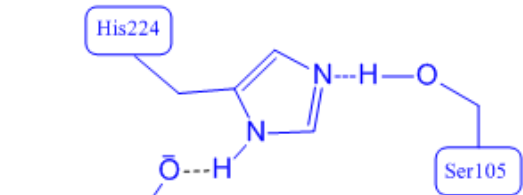

Lipase Active Site
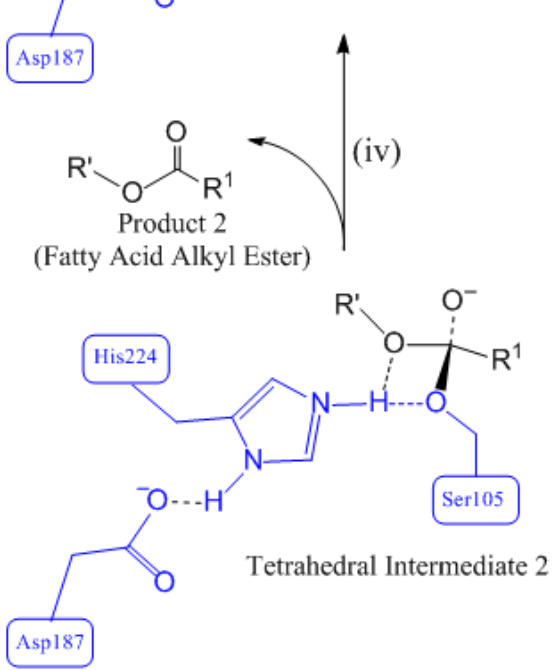

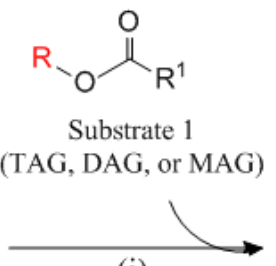

(i)

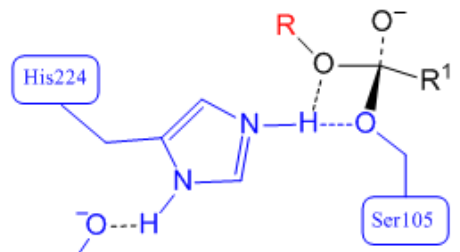

Tetrahedral Intermediate 1

(ii)
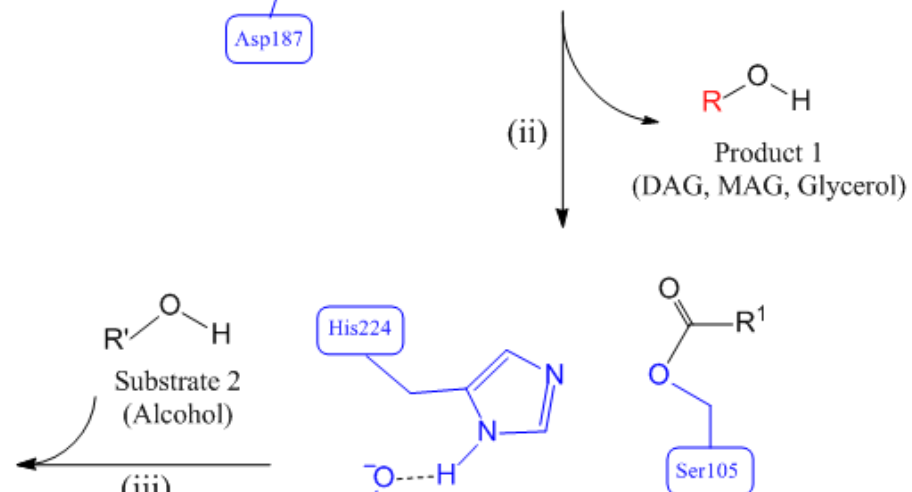

(iii)

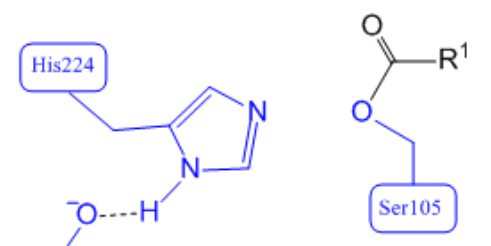

Enzyme-Substrate Complex

Figure 4. Lipase catalytic cycle for fatty acid alkyl ester (biodiesel) production. The cycle of reactions (i-iv) is repeated until all of the acylglycerols (TAG, DAG, MAG) are converted to fatty acid alkyl esters and a glycerol is formed.

Many lipases have been tested for enzymatic biodiesel synthesis, but the highest activity and yield of fatty acid alkyl esters have been observed with CalB (Mateo et al. 2002). Additionally, CalB has showcased greater stability at higher temperatures (60$80^{\circ} \mathrm{C}$ ) for long durations, an essential factor for use in multiple cycles. It is an additional advantage that CalB has a stable open conformation active site, not requiring interfacial activation for solvent and substrate accessibility like most lipases (Martinelle et al. 1995). There are some classes of lipases that in the presence of certain substrates or solvents 
cannot undergo interfacial activation, such as Rhizomucor miehei, which has no effect in ethanol (Uppenberg et al. 1994b).

\section{Implementation of an Enzymatic Biodiesel Process}

Overall, the advantages of lipase biocatalysts counter most of the obstacles in traditional biodiesel production methods, such as higher purity product yield, easier recovery of glycerol, milder reaction conditions, and regeneration and reuse of the catalyst over several cycles, as well as many additional advantages such as greater selectivity of substrates and alcohols, higher thermal stability, and ability to react in both solvent and solvent-free systems (Akoh et al. 2007). However, the one major drawback of enzymatic biodiesel production is the cost of the lipase enzyme, which is considerably more expensive than chemical catalysts (Villeneuve et al. 2000). By using DNA recombinant technology, optimization of lipases and development of strains to express large quantities of these biocatalysts are essential for inexpensive production of biodiesel.

One of the current objectives in this area of research is to prepare a highly active, stable, low-cost lipase expressed at high levels in an ethanologenic yeast strain that can be incorporated into ethanol production facilities (Hughes et al. 2011). Most fuel ethanol is produced from corn starch, which yields substantial amounts of low quality corn oil as a byproduct. On-site lipase biocatalytic processes could convert this corn-oil byproduct into fatty acid ethyl esters and glycerol using both the starch ethanol produced from the dry grind processes and the cellulosic ethanol produced by the yeast. This concept of an integrated biorefinery may be a potential cost-effective solution if biodiesel could be produced simultaneously with ethanol. In order to achieve this, a catalytic column 
process could be implemented in which these low-cost lipases expressed in ethanologenic yeast are immobilized on a resin packing the column, catalyzing the transesterification of ethanol and corn oil in a confined, single step and continuous method.

\section{Resin-bound Enzyme Immobilization}

One of the biggest advantages of lipase biocatalysts is their ability to be recovered and reused, but this benefit can only be accomplished by certain means. When using a free-form enzyme to catalyze a transesterification reaction it must be recovered from the glycerol product to be used again. However, the enzyme is only partially recoverable from the glycerol each time, and over multiple cycles the amount of glycerol product build-up causes enzyme activity to decrease. Eventually enzyme functionality will drop below reasonable levels or cease all together. The easiest and most effective solution is to immobilize the enzyme, preventing it from being immersed in the glycerol product and eliminating build-up and the need for extraction.

Lipases can be immobilized onto specialty resins, such as the Sepabead ${ }^{\circledR}$ EC-EP, a polymethacrylate bead containing epoxy functional groups on its surface. Modified lipases containing a polyhistidine tag can be anchored to the bead surface via covalent linkage with the epoxy functional groups (Mateo et al. 2000). Immobilization occurs in a two-step mechanism, in which the enzyme is first hydrophobically adsorbed on a polymethacrylate bead, and then nucleophilic substitution occurs between an enzyme amino group and the nearby epoxide group (Figure 5). The enzyme retains its function upon immobilization and the remaining epoxy groups can be blocked with different 
amine or thiol compounds to prevent unwanted intramolecular and external interactions with the anchored enzymes (Kramer et al. 1979).

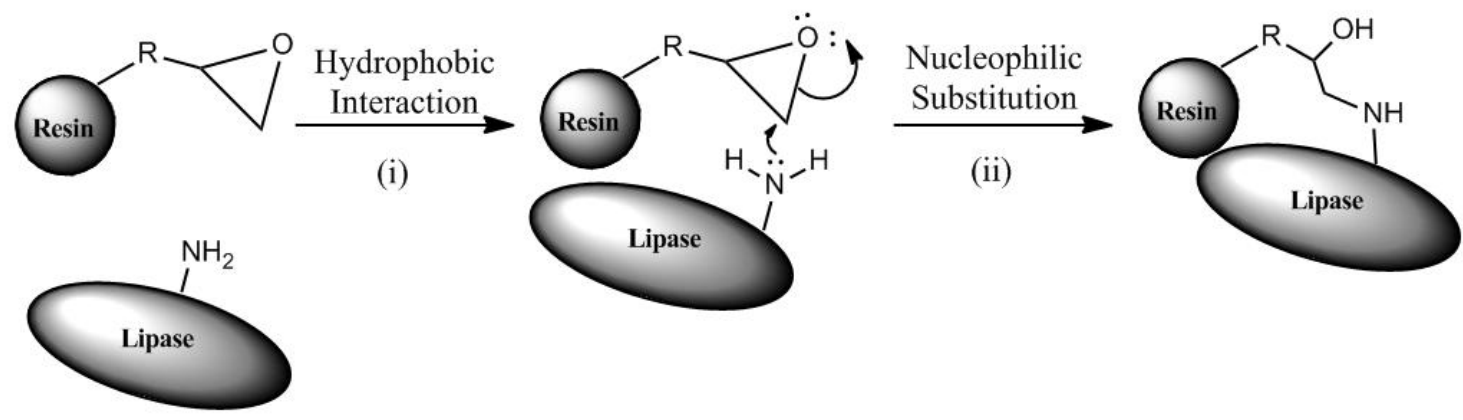

Figure 5. Schematic of lipase enzyme immobilization to a resin containing an epoxy functional group in two steps; enzyme adsorption to the resin hydrophobically (i), covalent linkage of an enzyme amino group to the epoxy functional group (ii).

Although these enzyme-binding resins are an additional expense to the already more costly enzymatic process, the easier recovery and longer reusability of immobilized enzymes compensate for the extra investment (Pessela et al. 2003). There are many additional benefits to immobilizing enzymes, such as increased stability which allows for longer storage duration. Additionally, immobilization increases enzyme stability, positively affecting other aspects such as prolonged transport. Lipase catalytic efficiency also increases because the active site can remain in an open conformation as a result of the adsorption of the enzyme on the resin surface.

\section{Purpose of Thesis}

The purpose of this thesis was to determine if a truncated CalB sequence transformed into the cellulosic ethanologenic yeast strain Saccharomyces cerevisiae (Hughes et al. 2011) had functional expression comparable to the wild-type enzyme. This 
project was a joint effort of both the United States Department of Agriculture National Center for Agricultural Utilization Research (USDA NCAUR) and Illinois State University. Research done at NCAUR was focused on immobilizing the truncated CalB protein on Sepabeads® EC-EP resin, and designing and performing various assays for production of fatty acid ethyl and butyl esters from corn oil or soybean oil triglycerides and cellulosic ethanol or n-butanol. Studies at ISU were focused on purification and determination of the specific activity of the truncated CalB. Enzyme assays using paranitrophenyl butyrate (p-NPB) were performed to determine the kinetic constants $\mathrm{K}_{\mathrm{m}}$ and $\mathrm{V}_{\max }$ of the truncated CalB, as well as the wild-type enzyme for comparison. 


\section{CHAPTER II}

\section{MATERIALS AND METHODS}

\section{Chemicals}

The following were obtained from Sigma Aldrich (St. Louis, MO): the lipase acrylic resin from Candida antarctica (Novozym 435); yeast (nitrogen base without amino acids; without amino acids); yeast (synthetic drop-out medium supplement without histidine, leucine, tryptophan, and uracil); L-leucine (non-animal source); L-tryptophan; L-histidine $\mathrm{H} 2 \mathrm{Cl} 2$; D-(+)-galactose; ammonium sulfate; potassium phosphate (monobasic and dibasic); acid washed glass beads (425-600 $\mu \mathrm{m})$; bovine serum albumin; tris(hydroxymethyl)aminomethane; Tween ${ }^{\circledR} 20$; octyl- $\beta$-D-glucopyranoside (OGP); ethylenediamine tetraacetic acid (EDTA) anhydrous; albumin, chicken egg (ovalbumin); AEC Chromogen Kit; p-nitrophenyl butyrate; ethanol; n-butanol; and hexane. Phosphatebuffered saline (1X) was purchased from Mediatech, Inc. (Manassas, VA). The Bacto ${ }^{\mathrm{TM}}$ Agar, Bacto ${ }^{\mathrm{TM}}$ Yeast, and Bacto ${ }^{\mathrm{TM}}$ Peptone were purchased from Becton, Dickinson and Company (Sparks, MD). Tris(hydroxymethyl)aminomethane hydrochloride, sodium dodecyl-sulfate, and 3-(N-morpholino)propanesulfonic acid (MOPS) were purchased from USB Corporation (Cleveland, OH). Triton X-100, sodium phosphate (monobasic) anhydrous, and sodium phosphate (dibasic) anhydrous were 
purchased from AMRESCO (Solon, OH). Nonidet P-40 was purchased from Midwest Scientific (St. Louis, MO). Sodium chloride, imidazole, dextrose (D-glucose) anhydrous (powder), potassium phosphate (monobasic), potassium phosphate (dibasic), acetic acid (glacial), acetonitrile, and methanol were purchased from Fisher Scientific (Pittsburgh, PA). Ammonium persulfate, TEMED (electrophoresis grade), acrylamide 40\% solution (electrophoresis grade), and glycine were purchased from Fisher BioReagents (Pittsburgh, PA). The BioRad ${ }^{\mathrm{TM}}$ protein reagent and $\beta$-mercaptoethanol were obtained from BioRad (Hercules, CA). HisProbe-HRP Working Solution was purchased from Thermo Fisher Scientific (Waltham, MA). InVision ${ }^{\mathrm{TM}}$ His-Tag In-gel Stain and SeeBlue ${ }^{\circledR}$ Plus2 Prestained Standard (1X) were purchased from Invitrogen (Carlsbad, CA). Penta-His antibody was purchased from QIAgen ${ }^{\circledR}$ (Valencia, CA). The soybean oil was obtained from KIC Chemicals, Inc. (New Paltz, NY). The corn oil was obtained from Lincolnland Agri-Energy (Palestine, IL).

\section{Supplies}

The Western Breeze ${ }^{\circledR}$ Chromogenic Immunodetection kit and PVDF membrane filter paper sandwich $0.2 \mu \mathrm{m}$ pore size were purchased from Invitrogen (Carlsbad, CA). The Sepabeads® EC-EP were obtained from Resindion (Binasco, MI-Italy). DIAION® resin was provided by Tai-Young Chemical Co., Ltd. (Taiwan). TALON® Metal Affinity Resin was purchased from Clontech Laboratories, Inc. (Mountain View, CA). Conical, $50 \mathrm{~mL}$ centrifuge tubes and semimicro polystyrene disposable cuvettes were purchased from Fisher Scientific (Pittsburgh, PA). Polypropylene $1.5 \mathrm{~mL}$ microcentrifuge tubes were purchased from Microstein (Central Point, OR). 


\section{Equipment}

The following equipment was used: UV/Vis spectrophotometer 8453, HewlettPackard Developmental Company, L.P. (Palo Alto, CA), Avanti J-20 and J-25I centrifuges, Beckman Coulter, Inc. (Fullerton, CA), C24 and innova ${ }^{\mathrm{TM}} 4230$ Incubator $^{2}$ Shaker, New Brunswick Scientific (Edison, NJ), Agilent model 6890 GC-FID equipped with a model 6890 series injector and an Agilent D8-5HT (15 m x $0.32 \mathrm{~mm}$ i.d., $0.10 \mu \mathrm{m}$

film thickness) column (Santa Clara, CA), AlphaImager ${ }^{\mathrm{TM}}$ System 3400 (Alpha Innotech Corporation, San Leandro, CA), French ${ }^{\circledR}$ Press and 40K pressure chamber (Thermo IEC), Sonicator bath (Fisher/Emerson).

\section{Selective Medium Plate Preparation}

A Saccharomyces cerevisiae diploid yeast strain PJ69-4 containing the plasmid pYES2 DEST 52 encoding a truncated version of the enzyme Candida antarctica lipase B (CalB; Hughes et al. 2011) was grown on plates of Complete Minimal 2\% Glucose minus Uracil (CM Glu -Ura) selective medium. This growth medium was prepared by adding 1.4 grams of yeast synthetic drop-out medium supplement without histidine, leucine, tryptophan, and uracil; 1.7 grams of yeast nitrogen base without amino acids; 0.06 grams of L-leucine; 0.04 grams of L-tryptophan; 0.02 grams of L-histidine; 5 grams ammonium sulfate; 20 grams of dextrose (D-Glucose); 20 grams of Bacto Agar and filled up to $1 \mathrm{~L}$ with Nanopure water in a Pyrex flask. The flask was then heat sterilized for 30 minutes at $250^{\circ} \mathrm{F}, 24$ pounds pressure per square inch using the liquid setting. Upon cooling to room temperature, the medium was plated and stored at $4{ }^{\circ} \mathrm{C}$ until ready to 
use. A volume of $10 \mu \mathrm{L}$ of truncated CalB::PJ69-4 was spotted on a CM Glu -Ura plate and incubated at $30{ }^{\circ} \mathrm{C}$ for 2 days. All work was done using sterile technique.

\section{Preparation of Liquid Media}

Two classes of liquid growth media were employed for this research: a selective medium, Complete Minimal Glucose minus Uracil (CM Glu -Ura), and a rich medium, Yeast Peptone Dextrose (YPD).

Selective medium CM Glu -Ura was prepared with 1.4 grams of yeast synthetic drop-out medium supplement without histidine, leucine, tryptophan, and uracil; 1.7 grams of yeast nitrogen base without amino acids; 0.06 grams of L-leucine; 0.04 grams of L-tryptophan; 0.02 grams of L-histidine; 5 grams ammonium sulfate; 20 grams of dextrose (D-glucose) and filled up to $1 \mathrm{~L}$ with Nanopure water in a Pyrex flask. The flask was then heat sterilized for 30 minutes at $250^{\circ} \mathrm{F}, 24$ pounds pressure per square inch using the liquid setting. Upon cooling to room temperature, the medium was stored at $4{ }^{\circ} \mathrm{C}$ until ready to use.

Rich medium YPD was prepared with 10 grams yeast extract, 20 grams Bacto Peptone, 20 grams dextrose (D-glucose) and filled up to $1 \mathrm{~L}$ with Nanopure water in a Pyrex flask. The flask was then heat sterilized for 30 minutes at $250^{\circ} \mathrm{F}, 24$ pounds pressure per square inch using the liquid setting. Upon cooling to room temperature, the medium was stored at $4{ }^{\circ} \mathrm{C}$ until ready to use. 
Additionally, a second type of medium was prepared with galactose (D-(+)-galactose) replacing dextrose as the sugar carbon source for both the selective medium (CM Gal -Ura) and rich medium (YPG).

\section{Preparation of Liquid Cultures}

All work was done using sterile technique and sterile commodities.

A liquid preculture was prepared by inoculating $25 \mathrm{~mL}$ of the selective growth medium CM Glu -Ura in a $150 \mathrm{~mL}$ Erlenmeyer flask with $S$. cerevisiae diploid strain PJ69-4 containing the plasmid pYES2 DEST 52 encoding the truncated CalB enzyme. After incubation for 2 days at $30{ }^{\circ} \mathrm{C}$ and $100 \mathrm{rpm}$, the optical density of the liquid cell

culture was measured by UV/Vis spectrophotometry. An absorbance value in the range of 1.5-1.8 at $660 \mathrm{~nm}$ was considered optimum cell growth. The cells were transferred to a 4-L Erlenmeyer flask containing $1 \mathrm{~L}$ of rich medium YPD and incubated for 2 days at $30{ }^{\circ} \mathrm{C}$ and $100 \mathrm{rpm}$. The culture was centrifuged for $20 \mathrm{~min}$ at $3200 \mathrm{rpm}$. The supernatant was decanted and the cell pellet was transferred into another 4-L Erlenmeyer flask containing $1 \mathrm{~L}$ of YPG rich medium. After incubation for 2 days at $30{ }^{\circ} \mathrm{C}$ and $100 \mathrm{rpm}$, the culture was centrifuged again for $20 \mathrm{~min}$ at $3200 \mathrm{rpm}$. Supernatant was decanted and $80 \mathrm{~mL} 50 \mathrm{mM}$ Tris, $100 \mathrm{mM} \mathrm{NaCl}$, pH 7.5 buffer was added to the cell pellet, then divided into four separate 50-mL centrifuge tubes, each holding approximately $20 \mathrm{~mL}$ of the liquid cell suspension, and stored at $-20^{\circ} \mathrm{C}$ overnight. 


\section{Cell Lysis and Protein Extraction}

Two cell lysis methods were employed in this research.

\section{Method Utilized at NCAUR, USDA}

The yeast cell pellet was thawed on ice and resuspended in an equal volume (v/v) of Yeast-Protein Extraction Reagent (Y-PER) and placed in a 60-cc syringe containing $3.0 \mathrm{~mL}$ of acid-washed $425-600 \mu \mathrm{m}$ glass beads and equipped with an 18 gauge needle. The cell pellet was forced through the glass beads via force from the syringe plunger. The resulting cell lysate was poured into a sterile, chilled container and repeatedly passed through the glass beads a total of five times. Yeast cell rupture was confirmed via visualization by light microscopy.

\section{Method Utilized at Illinois State University}

A French® Press apparatus was utilized, in which a hydraulic pump drives a piston into a metal cylinder (pressure chamber) containing a liquid suspension of cells, forcing the cells through a narrow valve under high pressure. The $40 \mathrm{~K}$ psi pressure chamber and 1 inch piston were chilled to $4{ }^{\circ} \mathrm{C}$ before use. Prior to lysis, cell pellet was thawed in a $200 \mathrm{~mL}$ beaker of tap water, then placed on ice, and $40 \mu \mathrm{L}$ of $0.1 \mathrm{M}$ EDTA was added to $20 \mathrm{~mL}$ yeast cell suspension. After setting the gauge to 1800 psi (estimated 30,000 psi internal cell pressure) in high position, the yeast cells were ruptured and collected in a chilled 50 -mL centrifuge tube. After setting aside $500 \mu \mathrm{L}$ of the crude extract to be used for analysis, the remaining crude extract was centrifuged for $20 \mathrm{~min}$ at $15,000 \mathrm{rpm}$ at a temperature of $4{ }^{\circ} \mathrm{C}$. The cell supernatant was decanted into a $50-\mathrm{mL}$ 
centrifuge tube and chilled on ice; $500 \mu \mathrm{L}$ was set aside for analysis. The cell pellet was stored at $-20{ }^{\circ} \mathrm{C}$.

\section{Protein Solubilization with Detergents}

Following cell lysis in some trials, different detergents were employed for further isolation of the CalB protein. After running the yeast cell suspension through the French ${ }^{\circledR}$ Press apparatus, the crude lysate was collected in a chilled 50 -mL centrifuge tube, with $500 \mu \mathrm{L}$ set aside for analysis. A portion of the crude lysate, typically around half the volume, was placed in a separate $50 \mathrm{~mL}$ tube and centrifuged for $20 \mathrm{~min}$ at $15,000 \mathrm{rpm}$ at a temperature of $4{ }^{\circ} \mathrm{C}$. The cell supernatant was decanted into a $50-\mathrm{mL}$ centrifuge tube, with $500 \mu \mathrm{L}$ set aside for analysis. To the remaining cell pellet, $10 \mathrm{~mL}$ of various detergent solutions were added (Appendix A). Using a Dounce Homogenizer, the yeast cell suspension containing the detergent was poured into the glass tube, then the pestle was inserted and pressed down, then lifted, with the up and the down motion repeated several times, creating a liquid shear capable of further lysing the yeast cells. After collecting $500 \mu \mathrm{L}$ for analysis, the yeast cell suspension was centrifuged for $20 \mathrm{~min}$ at $15,000 \mathrm{rpm}$ at a temperature of $4{ }^{\circ} \mathrm{C}$ and the cell supernatant was decanted into a 50-mL centrifuge tube, with $500 \mu \mathrm{L}$ set aside for analysis. The remaining cell pellet was resuspended in $10 \mathrm{~mL}$ of $50 \mathrm{mM}$ Tris, $100 \mathrm{mM} \mathrm{NaCl}, \mathrm{pH} 7.5$ buffer. 


\section{Protein Isolation and Purification}

Two methods were used in this research to isolate the enzyme.

\section{Method Utilized at NCAUR, USDA}

A volume of $1 \mathrm{~mL}$ QIAgen® Superflow Nickel Beads, capable of binding $20 \mathrm{mg}$ of His-tagged protein per $1 \mathrm{~mL}$ slurry, was added to the lysed yeast cells in a $50-\mathrm{mL}$ tube and the mixture was incubated overnight at $4{ }^{\circ} \mathrm{C}$ with low speed tumbling.

\section{Method Utilized at Illinois State University}

IMAC (Immobilized Metal Affinity Column) was utilized to isolate the enzyme. After assembling the column, TALON $®$ resin was added and the column was securely fastened at a necessary height to allow for gravity to siphon the elution buffer and cell pellet solution. A 125-mL flask containing $100 \mathrm{~mL} 50 \mathrm{mM}$ Tris, $100 \mathrm{mM} \mathrm{NaCl}$, pH 7.5 buffer was fastened above the column and $50 \mathrm{~mL}$ was siphoned through the column and collected in an empty beaker. The supernatant from the crude extract was poured into a 125-mL flask and diluted to $100 \mathrm{~mL}$ with $50 \mathrm{mM}$ Tris, $100 \mathrm{mM} \mathrm{NaCl}, \mathrm{pH} 7.5$ buffer. After fastening above the column, the $100 \mathrm{~mL}$ of diluted supernatant was siphoned through the column. The eluate was collected in a separate flask labeled "flow-through" and set aside. Immediately following the complete elution of the diluted supernatant $50 \mathrm{~mL}$ of the $50 \mathrm{mM}$ Tris, $100 \mathrm{mM} \mathrm{NaCl}$, pH 7.5 buffer was eluted through the column into a flask labeled "buffer wash". Siphoning was halted and $50 \mathrm{~mL}$ of $10 \mathrm{mM}$ imidazole, $\mathrm{pH} 7.5$ buffer was added to the same flask and eluted through the column into a flask labeled "10 mM Im buffer". After the last of the eluate was collected and the valve 
closed, the top of the column was removed and $10 \mathrm{~mL}$ of $200 \mathrm{mM}$ imidazole, $\mathrm{pH} 7.5$ buffer was pipetted directly into the column. Ten 1.5-mL microcentrifuge tubes were labeled 1-10 and placed single file chronologically in a holder beneath to column. The eluate valve was opened and approximately $1 \mathrm{~mL}$ of eluate was collected in sample tube 1 and the process repeated until all ten sample tubes contain $1 \mathrm{~mL}$ of eluate.

\section{BioRad Protein Assay}

The unknown protein concentrations of each fraction collected from the IMAC column, as well as the other eluate solutions, the crude extract, and cell supernatant were determined using the method of Bradford (1976) (Appendix B). A standard curve was constructed using Bovine Serum Albumin (BSA) with concentrations in milligrams per milliliter $(\mathrm{mg} / \mathrm{mL})$.

\section{Binding Enzyme to Resin}

After incubation at $37^{\circ} \mathrm{C}$, approximately $2.5 \mathrm{~mL}$ of the lysed yeast cells were placed into four separate $50-\mathrm{mL}$ tubes and centrifuged at $3200 \mathrm{rpm}$ for $15 \mathrm{~min}$. The supernatant from each sample was decanted into a secondary 50-mL tube. The remaining pellet in the first set of four tubes was resuspended in $2 \mathrm{~mL}$ of $20 \mathrm{mM}$ phosphate-buffered saline (PBS) pH 7 with $2 \mathrm{M}$ ammonium sulfate equilibrium buffer, also serving as the resin-charging buffer (Silvia et al. 2006), and centrifuged a second time. The supernatant was decanted into the corresponding secondary tube containing the previously poured supernatant, and the process was repeated once more. 
To the first set of the four tubes containing the pooled supernatant, $1.5 \mathrm{~mL}$ of EC-EP Sepabeads® resin and $5.0 \mathrm{~mL}$ of $2 \mathrm{M}$ ammonium sulfate resin-charging buffer were added to each tube. To each of the second set of the 4 tubes containing pelleted cells, $1.5 \mathrm{~mL}$ resin and $2.0 \mathrm{~mL}$ buffer were added. Additionally, $0.5 \mathrm{~mL} 300 \mathrm{mM}$ EDTA was added to elute any lipase bound to the QIAgen® Superflow Nickel Beads.

A third set of four 50-mL tubes was prepared containing approximately $2.5 \mathrm{~mL}$ of acrylic resin with Novozym 435 and $2.5 \mathrm{~mL} 2 \mathrm{M}$ ammonium sulfate resin-charging buffer. A single 50-mL tube containing $1.5 \mathrm{~mL}$ EC-EP Sepabeads $®$ resin and $2.5 \mathrm{~mL}$ resin-charging buffer was also prepared. The three sets of tubes and the EC-EP Sepabeads ${ }^{\circledR}$ control tube were tumbled for $16-18$ hrs at $30{ }^{\circ} \mathrm{C}$. After incubation, tubes were centrifuged for 15-20 min at $3200 \mathrm{rpm}$, and the supernatant was removed.

A fourth set of four $50-\mathrm{mL}$ tubes containing $1.5 \mathrm{~mL}$ of DIAION® weakly acidic cation exchange resin were also prepared.

\section{Fatty Acid Alkyl Ester Production}

To assess the capability of the resin-bound truncated CalB to produce fatty acid alkyl esters, varying mixtures of alcohol and vegetable based oils were prepared (Appendix C). The amount of alcohol/oil mixture added to each tube containing the resinbound truncated CalB was based on a 2:1 (v/v) ratio of mixture to lipase-bound EC-EP Sepabeads ${ }^{\circledR}$ resin or DIAION® ionic resin. All tubes were tumbled and incubated for 16-18 hours at $37^{\circ} \mathrm{C}$. 


\section{Analysis by Gas Chromatography}

After incubation, a 1:1 (v/v) ratio of hexane to sample was added to the content of each tube. The samples were vigorously shaken and then centrifuged for 15-20 min at $3200 \mathrm{rpm}$. From each sample, $100 \mu \mathrm{L}$ was collected from the hexane layer and pipetted into an individual vial containing $1 \mathrm{~mL}$ of hexane. The hexane samples were analyzed for fatty acid alkyl ester production using gas chromatography followed by mass spectrometry (GC/MS). The injection volume was $1 \mu \mathrm{L}$. The carrier gas was helium at a flow rate of $3 \mathrm{~mL} / \mathrm{minute}$. The oven temperature was initially held at $50{ }^{\circ} \mathrm{C}$ for 1 minute, increased to $180{ }^{\circ} \mathrm{C}$ at $15 \mathrm{C} /$ minute, to $230{ }^{\circ} \mathrm{C}$ at $7{ }^{\circ} \mathrm{C} /$ minute, and to $380{ }^{\circ} \mathrm{C}$ at $30{ }^{\circ} \mathrm{C} /$ minute, and held for 10 minutes at $380{ }^{\circ} \mathrm{C}$. Using the same injection volume and gas chromatography conditions as the samples, $1 \mu \mathrm{g}$ of triacylglycerols (TAG), diacylglycerols (DAG), monoacylglycerols (MAG), and ethyl esters (EE) were used as standards to evaluate retention times of the fatty acid alkyl ester products.

\section{SDS-PAGE}

Polyacrylamide gels, $4 \%$ stacking gel and $12 \%$ resolving gel, were prepared using deionized water, $40 \%(\mathrm{w} / \mathrm{v})$ acrylamide solution, $10 \%(\mathrm{w} / \mathrm{v})$ sodium dodecyl sulfate (SDS), and 1.5 M Tris- $\mathrm{HCl} \mathrm{pH} 8.8$ for the $12 \%$ resolving gel or $1.0 \mathrm{M}$ Tris- $\mathrm{HCl} \mathrm{pH} 6.8$ for the $4 \%$ stacking gel. A $10 \%(\mathrm{w} / \mathrm{v})$ ammonium persulfate (APS) solution was prepared, and $0.1 \mathrm{~mL} \mathrm{10 \%} \mathrm{APS} \mathrm{and} 4 \mu \mathrm{L}$ tetramethylethylenediamine (TEMED) were added to the $12 \%$ resolving gel solution. The acrylamide solution was poured between two glass holding plates and a $200 \mu \mathrm{L}$ layer of isopropanol was added to the top of the gel solution. A set time of 10-15 minutes was allotted for the acrylamide to polymerize. The 
isopropanol layer was rinsed away with deionized water, and upon addition of $40 \mu \mathrm{L} 10 \%$ APS and $4 \mu \mathrm{L}$ TEMED the $4 \%$ stacking gel solution was pipetted atop the set resolving gel. Upon placement of a 10-well comb, a second set time of 10-15 minutes was allotted for polymerization of the stacking gel solution.

Two sets of samples were prepared and analyzed separately in this research.

\section{Method Utilized at NCAUR, USDA}

Three $1 \mathrm{~mL}$ samples of the rich medium YPD and YPG culture, following incubation, each placed in a $1.5 \mathrm{~mL}$ microcentrifuge tube, were centrifuged for 2 minutes at $13000 \mathrm{rpm}$. The supernatant from each sample was transferred to a separate $1.5 \mathrm{~mL}$ microcentrifuge tube. After diluting $2 \mathrm{~mL} \beta$-mercaptoethanol in $20 \mathrm{~mL} 2 \mathrm{X}$ Tris-Tricine loading buffer ( $\mathrm{pH} 8.3$ ), $40 \mu \mathrm{L}$ was added to the pellet and supernatant samples. Samples were resuspended and heated at $95{ }^{\circ} \mathrm{C}$ for 10 minutes, then $10 \mu \mathrm{L}$ of each sample was loaded onto the polyacrylamide gel, as well as $3 \mu \mathrm{L}$ of SeeBlue ${ }^{\circledR}$ Plus2 Pre-stained Standard and $3 \mu \mathrm{L}$ His marker. Samples were run in 1X Tris-Tricine electrophoresis buffer at 125 volts for 100 minutes.

\section{Method Utilized at Illinois State University}

Samples were prepared by using $75 \mu \mathrm{L}$ aliquots for all fractions and $25 \mu \mathrm{L}$ of $4 \mathrm{X}$ SDS bromophenol blue buffer (Tris-HCl pH 6.8, $10 \%$ (w/v) SDS, glycerol, 4\% (w/v) bromophenol blue in ethanol). The samples were heated at $95^{\circ} \mathrm{C}$ for 10 minutes. Additionally, one set of samples was run with 2X SDS Tris-Tricine loading buffer ( $\mathrm{pH} 8.3$ ) containing a dilute amount of $\beta$-mercaptoethanol. Typical volumes loaded into 
the gel wells were $20 \mu \mathrm{L}$ of protein fraction samples, $10 \mu \mathrm{L}$ of SeeBlue ${ }^{\circledR}$ Plus 2 prestained molecular weight (MW) standards, and $5 \mu \mathrm{L}$ His marker and $3 \mu \mathrm{L}$ His control protein for gels intended for Western Blot analysis. The gels were run in 1X Tris-Glycine electrophoresis buffer at $150 \mathrm{~V}$ for one hour.

\section{Coomassie Protein Stain}

Following electrophoresis, the gels were removed from the glass plates and placed in a saturated Bio-Rad Coomassie Brilliant Blue R-250 Staining Solution (45\%, v/v, methanol, 10\%, v/v, acetic acid) and gently shaken for a minimum of 30 minutes. After staining, the gels were placed in destain solution $(45 \%, \mathrm{v} / \mathrm{v}$, methanol, $10 \%, \mathrm{v} / \mathrm{v}$, acetic acid) and gently shaken until individual protein bands were visible. Following destaining, the gels were sealed in shrink wrap and air dried, then scanned for an electronic copy. The MW standard protein ladder was used to estimate the molecular weight of the truncated CalB protein.

\section{Western Blot Analysis}

One liter of transfer buffer was prepared using Nanopure water, $25 \mathrm{mM}$ Tris-Base pH 8.3, $192 \mathrm{mM}$ glycine, and 20\% (v/v) methanol. A polyvinylidene difluoride (PVDF) membrane was charged in $20 \mathrm{~mL}$ methanol for 1 minute, then additionally in $20 \mathrm{~mL}$ transfer buffer, along with several layers of filter paper. After assembling the blotting apparatus by securely placing the SDS-PAGE gel and PVDF membrane between the filter paper, transfer buffer was poured into the chamber until complete submersion of the blotting apparatus. The electric current was set to $160 \mathrm{~mA}$ and run for 650 minutes. 
One liter TBS-T blocking buffer was prepared using Nanopure water, $25 \mathrm{mM}$ Tris- $\mathrm{HCl}, 0.15 \mathrm{M} \mathrm{NaCl}$, and $0.05 \%$ (v/v) Tween-20. A non-specific protein binding blocking solution was prepared using $2.5 \mathrm{~g}$ ovalbumin in $100 \mathrm{~mL}$ TBS-T buffer upon gentle heating and stirring. The blotting apparatus was disassembled and the PVDF membrane carefully removed and placed in a tray containing $50 \mathrm{~mL}$ of the blocking solution and gently shaken for 1 hour at room temperature. The membrane was washed twice in $25 \mathrm{~mL}$ of TBS-T blocking buffer, gently shaken for 10 minutes, and then incubated in a dilute solution of Penta-His Mouse primary antibody for 1 hour. Following rinsing twice with $15 \mathrm{~mL}$ TBS-T, the membrane was incubated in $10 \mathrm{~mL}$ of the secondary antibody solution, which was a $4 \mathrm{mg} / \mathrm{mL}$ stock of HisProbe-HRP (horseradish peroxidase) Working Solution diluted 1:5000 in TBS-T blocking buffer, for 1 hour and then rinsed four times in $15 \mathrm{~mL}$ TBS-T buffer. AEC (3-amino-9-ethylcarbazole) Substrate Reagent was prepared by mixing $4 \mathrm{~mL}$ Nanopure water, 2 drops $2.5 \mathrm{M}$ acetate buffer $\mathrm{pH}$ 5.0, 1 drop AEC in N,N-dimethylformamide, and 1 drop 3\% (v/v) hydrogen peroxide in deionized water, and after applying 2-3 drops of the solution to the PVDF membrane, it was incubated for 10 minutes until the appearance of a red precipitate at the protein bands developed.

Alternatively, a Western Breeze ${ }^{\circledR}$ Chromogenic Kit, anti-mouse antibody was used for band detection. For this method, the PVDF membrane was incubated in $10 \mathrm{~mL}$ of prepared Blocking Solution, consisting of $2 \mathrm{~mL}$ concentrated buffered saline solution containing detergent (Blocker A), $3 \mathrm{~mL}$ concentrated Hammersten casein solution (Blocker B), with $5 \mathrm{~mL}$ Nanopure water, and gently shaken for 1 hour at room 
temperature. The solution was decanted and the membrane was rinsed in $20 \mathrm{~mL}$ of Nanopure water for 5 minutes, decanted and rinsing repeated one more time. The membrane was then incubated in $10 \mathrm{~mL}$ of Primary Antibody Solution, consisting of QIAgen ${ }^{\circledR}$ Penta-His Mouse primary antibody diluted 1:1000 in $2 \mathrm{~mL}$ Blocker A solution, $1 \mathrm{~mL}$ Blocker B solution, with $7 \mathrm{~mL}$ Nanopure water, and gently shaken for 1 hour at room temperature. The solution was decanted and the membrane was rinsed in $20 \mathrm{~mL}$ of a prepared Antibody Wash, a 16X concentrated buffered saline solution containing detergent diluted in Nanopure water, for 5 minutes and decanted, then repeated three more times. The membrane was then incubated in $10 \mathrm{~mL}$ of Secondary Antibody Solution, a prepared solution of alkaline phosphatase-conjugated, affinity purified, antimouse $\mathrm{IgG}$ (goat conjugate), and gently shaken for 30 minutes at room temperature. After decanting the solution, the membrane was rinsed in $20 \mathrm{~mL}$ of the Antibody Wash for 5 minutes and decanted, then repeated three more times. After decanting the wash solution, the membrane was rinsed in $20 \mathrm{~mL}$ of Nanopure water for 2 minutes and decanted. The membrane was then incubated in $5 \mathrm{~mL}$ of the Chromogenic Substrate, BCIP (5-bromo-4-chloro-3-indolyl-phosphate) used in conjunction with NBT (nitro blue tetrazolium) for the detection of alkaline phosphatase activity, and gently shaken for 1 hour at room temperature, until the appearance of a purple precipitate at the protein bands developed. The membrane was rinsed in $20 \mathrm{~mL}$ of Nanopure water for 2 minutes, decanted and repeated two more times. The PVDF membrane was air-dried overnight on a clean piece of filter paper. 


\section{Densitometry}

The dried PVDF membrane containing visible protein bands was analyzed by an AlphaImager ${ }^{\mathrm{TM}}$ System 3400 to determine band density. The Integrated Density Value (IDV) of the $38 \mathrm{kDa}$ band (concentration $0.27 \mu \mathrm{g} / 3 \mu \mathrm{L}$ ) in the SeeBlue ${ }^{\circledR}$ Plus 2 Standard was used to estimate protein concentration.

\section{Enzyme Activity}

After the highest concentration of protein of the purified fractions was identified, the activity of the truncated CalB was measured in a series of kinetic assays using the substrate para-nitrophenyl butyrate (p-NPB) and measuring the generation of product, para-nitrophenol (p-NP) using UV/Vis spectrophotometry. All absorption measurements were taken using a Hewlett-Packard UV/Vis spectrophotometer 8453 in the kinetics mode setting at room temperature. Two different kinetic assay methods were utilized in determining the specific activity of the truncated CalB.

The first method was taken from Blank et al. (2006). First, a $20 \mathrm{mM}$ stock solution of p-NPB was prepared in ethanol. The buffer prepared for the assay mixture consisted of $50 \mathrm{mM}$ sodium phosphate, $\mathrm{pH} 7.0,150 \mathrm{mM} \mathrm{NaCl}, 0.5 \%$ (v/v) Triton X-100, and 5\% (v/v) ethanol. Various concentrations of the substrate p-NPB were used and solutions were prepared from the $20 \mathrm{mM}$ stock solution as presented in Appendix D. The assay buffer, substrate solution, and ethanol were mixed in a polystyrene cuvette and a background rate was determined by measuring the absorption at $405 \mathrm{~nm}$ every 0.9 seconds for 60 seconds. The reaction was initiated by addition to the mixture of $5 \mu \mathrm{L}$ 
of the truncated CalB taken from the purified protein fraction containing the highest concentration of protein measured, and the generation of product, para-nitrophenol (p-NP) was followed by measuring the increase of absorbance at $405 \mathrm{~nm}$ every 0.9 seconds for a total of 300 seconds. All measurements were carried out in triplicate.

The second method was that proposed by Martinelle et al. (1995); the p-NPB was dissolved and diluted in acetonitrile in a $1.5-\mathrm{mL}$ microcentrifuge tube, then added to a glass culture tube containing the buffer solution, $50 \mathrm{mM}$ MOPS, $\mathrm{pH} 7.5$, to equal a total volume of $990 \mu \mathrm{L}$, with a total of three samples prepared per varying concentration of p-NPB (Appendix D). The concentration of acetonitrile was kept constant at $1 \%(\mathrm{v} / \mathrm{v})$. Samples were placed in a sonicator bath for 2 minutes at room temperature, and then transferred to a quartz cuvette. The background rate was measured using the same method as used formerly, and then $10 \mu \mathrm{L}$ of truncated CalB from the purified fraction was added to the cuvette to initiate the reaction. The reaction rate was measured over a period of 180 seconds with absorption at $400 \mathrm{~nm}$ measured every 0.9 seconds. Measurements were carried out in triplicate.

The activity of the full-length CalB was measured using the method of Martinelle et al. (1995). A recombinant version was used in place of the commercially available fulllength CalB enzyme, Novozym 435, in order to reproduce identical work-up conditions as the truncated CalB. After obtaining a background rate, $10 \mu \mathrm{L}$ of the full-length CalB enzyme was added to the cuvette to initiate the reaction. The reaction rate was measured over a period of 180 seconds with absorption at $400 \mathrm{~nm}$ measured every 0.9 seconds. Measurements were carried out in triplicate. 
All initial reaction velocity values, $\mathrm{V}_{0}$, taken in triplicate were averaged. A Michaelis-Menten plot was constructed using the collected data for the truncated and fulllength CalB. A non-linear regression using the Microsoft ${ }^{\circledR}$ Excel program was performed with the data to determine the values for the kinetic constants $\mathrm{V}_{\max }$ (maximal rate or velocity) and $\mathrm{K}_{\mathrm{m}}$ (Michaelis-Menten constant). 


\section{CHAPTER III \\ RESULTS AND DISCUSSION \\ Expression of Truncated CalB in Growth Medium}

A modified sequence for CalB containing six in-frame ATG codons was inserted into the pYES-DEST 52 plasmid and transformed into the diploid Saccharomyces cerevisiae yeast strain PJ69-4. Cultures of this yeast strain were grown in glucose medium, and then later transferred to a galactose medium. Samples were analyzed by SDS-PAGE and Western blot analysis to determine which of the six possible truncated CalB sequences was expressed in the PJ69-4 yeast strain in glucose then galactose medium.

The Western blot analysis of the PJ69-4 yeast cultures showed minimal to no expression of the six possible CalB variants when grown in glucose (Figure 6; left). There was a trace amount of CalB at $28.4 \mathrm{kDa}$ detectable in the lanes with the pellet samples. When the cultures were switched from glucose to galactose (Figure 6; right), expression of five of the possible six truncated CalB variants, driven by activation of the Gal1 promoter, was observed at $33.8 \mathrm{kDa}, 31.4 \mathrm{kDa}, 29.7 \mathrm{kDa}, 28.4 \mathrm{kDa}$, and $23.5 \mathrm{kDa}$. All CalB proteins, except the $23.5 \mathrm{kDa}$ variant, contain the complete Asp187-His224Ser105 catalytic triad. The CalB variant at $33.8 \mathrm{kDa}$ had the highest level of expression, with most of the enzyme localized to the cell pellet at $4.85 \mathrm{mg} / 10 \mathrm{~mL}$ and only a small 
amount present in the supernatant at $1.5 \mathrm{mg} / 10 \mathrm{~mL}$, measured using the integrated density value (IDV) compared to that of SeeBlue ${ }^{\circledR}$ Plus2 Standard. The IDV is the density of the protein band $(\mathrm{ng} / \mu \mathrm{L})$ at a specific molecular weight $(\mathrm{kDa})$. These values are relative to the loading buffer and are determined by densitometry, the measuring of protein band optical intensity with an imager. This is a common way to quantify Western blot data.
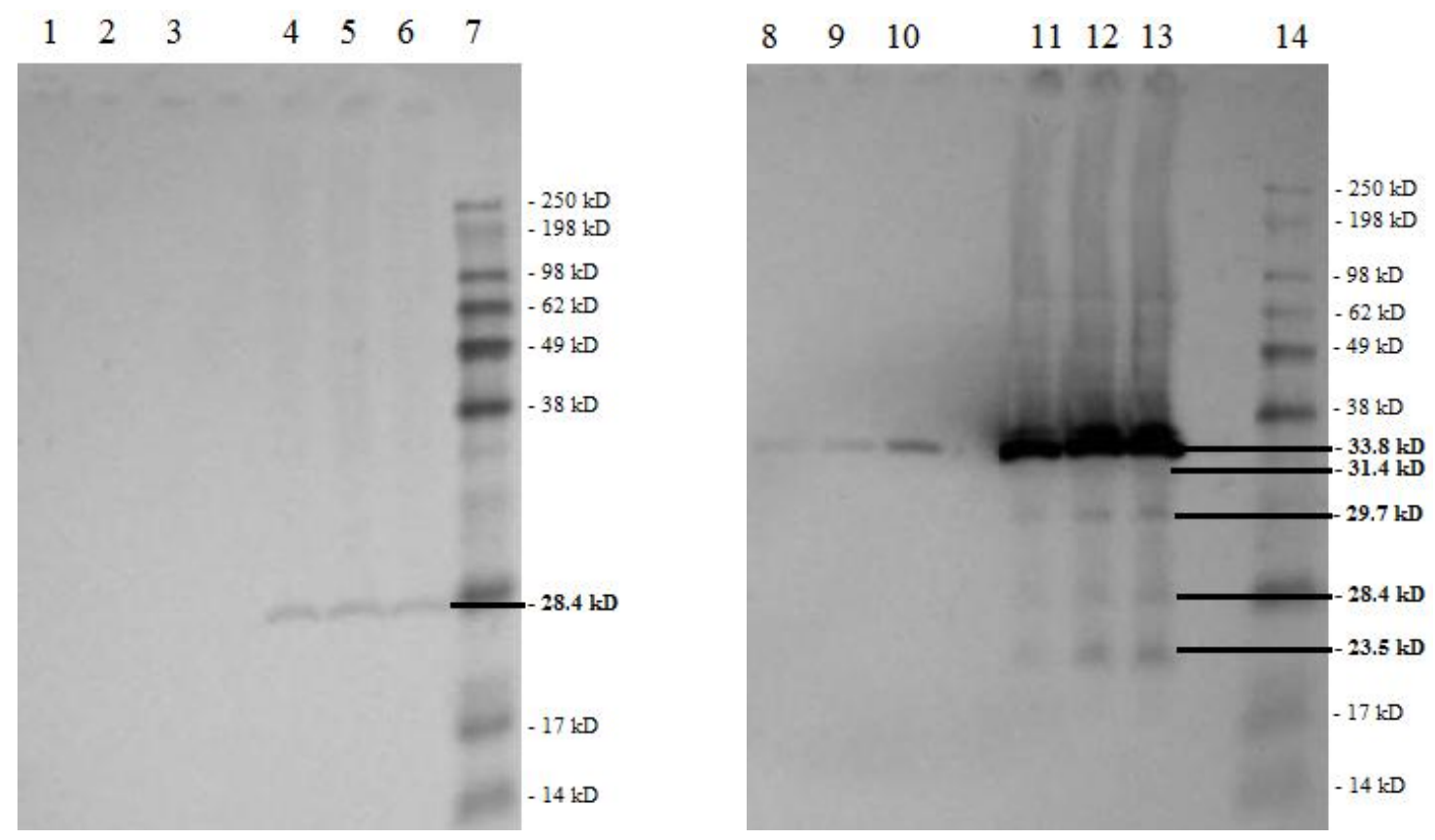

Figure 6. Western blot analysis of six CalB variants in PJ69-4 yeast cultures when grown in glucose (YPD) medium (left), and when switched to galactose (YPG) medium (right).

$\underline{\text { Lane }}$ Components

$1-3$

4-6

7

$8-10$

11-13

14
Cell Supernatant from Glucose Medium Cell Pellet from Glucose Medium His-tag Molecular Weight Standards (kDa) Cell Supernatant from Galactose Medium Cell Pellet from Galactose Medium His-tag Molecular Weight Standards (kDa) 


\section{Fatty Acid Ethyl Ester Production by Resin-bound Truncated CalB}

A 15:1 (v/v) ratio of ethanol and either corn or soybean oil was placed into a conical centrifuge tube containing either the truncated CalB or the commercial lipase Novozym 435 bound to Sepabead® EC-EP resin. The purpose of this experimental set-up was to determine which source of truncated CalB (cell pellet or supernatant), which oil source (corn or soybean), and which lipase enzyme (truncated CalB or Novozym 435), resulted in the greatest yield of fatty acid ethyl esters.

The results for fatty acid ethyl ester production from 15:1 (v/v) ratios of ethanol to either corn oil or soybean oil, using resin-bound truncated CalB from galactose rich medium (YPG) are presented in Figure 7. The commercially available lipase, Novozym 435 was used for comparison. The yield of fatty acid ethyl esters with 16 and 18 carbon chain lengths $(\mathrm{C} 16, \mathrm{C} 18)$ from supernatant per milligram of CalB ranged from 3.4 to 4.8 -fold greater than the yield per milligram of enzyme from the corresponding pelleted lysed cells with either corn oil or soybean oil. 


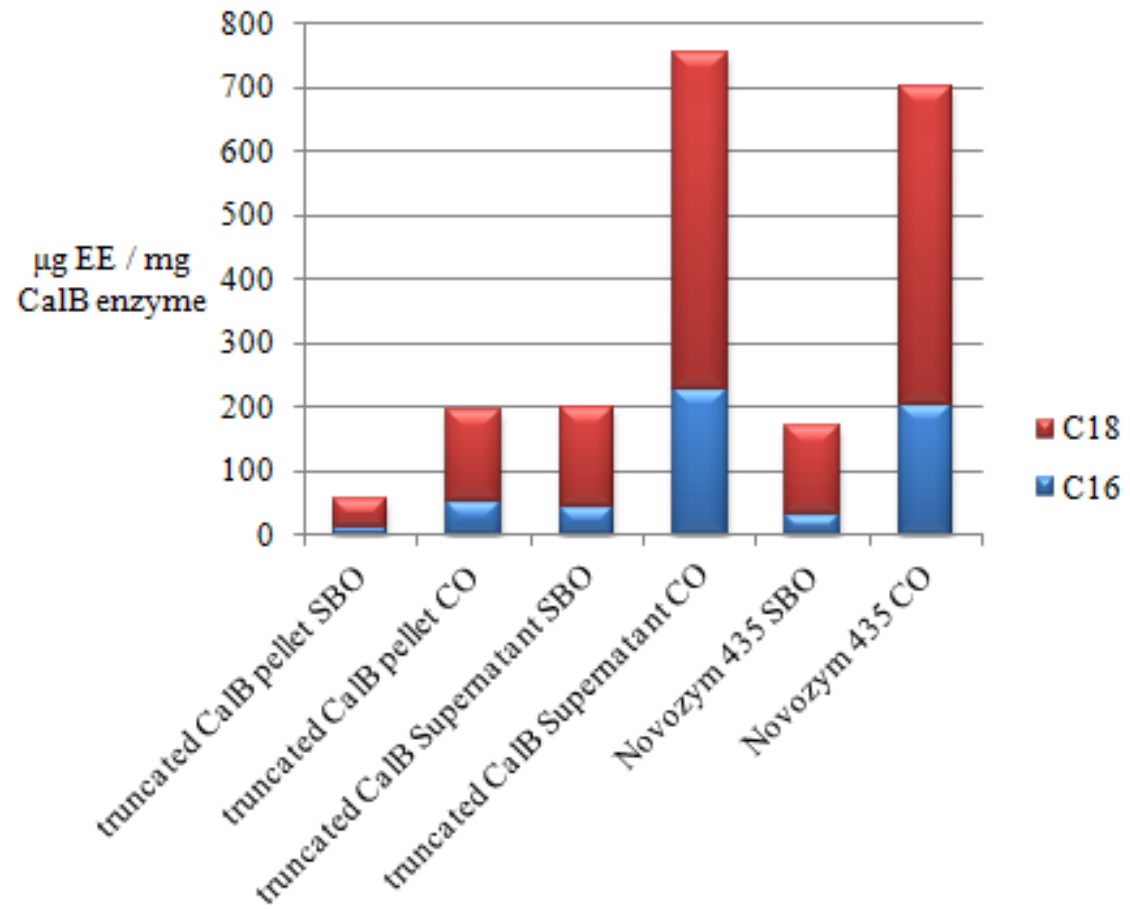

Figure 7. Fatty acid ethyl ester (EE) production per milligram of enzyme from corn oil (CO) or soybean oil (SBO) using resin-bound truncated CalB or Novozym 435 measured by gas chromatography. Data are single point determinations.

The results for total yield of $\mathrm{C} 16$ and $\mathrm{C} 18$ ethyl esters from supernatant and pellet are shown in Figure 8. The total yield of ethyl esters (EE) from corn oil was 36\% higher for truncated CalB with $951 \mu \mathrm{g} \mathrm{EE} / \mathrm{mg}$ enzyme than for the commercially available lipase, with $701 \mu \mathrm{gEE} / \mathrm{mg}$ enzyme. With soybean oil, the truncated CalB produced $255 \mu \mathrm{g} \mathrm{EE} / \mathrm{mg}$ enzyme, which is $50 \%$ more $\mathrm{C} 16$ and $\mathrm{C} 18$ ethyl esters than with the commercially available lipase with $170 \mu \mathrm{g} E \mathrm{E} / \mathrm{mg}$ enzyme. Both the truncated CalB and the commercial lipase gave a 4-fold greater yield of ethyl esters from corn oil than soybean oil. 


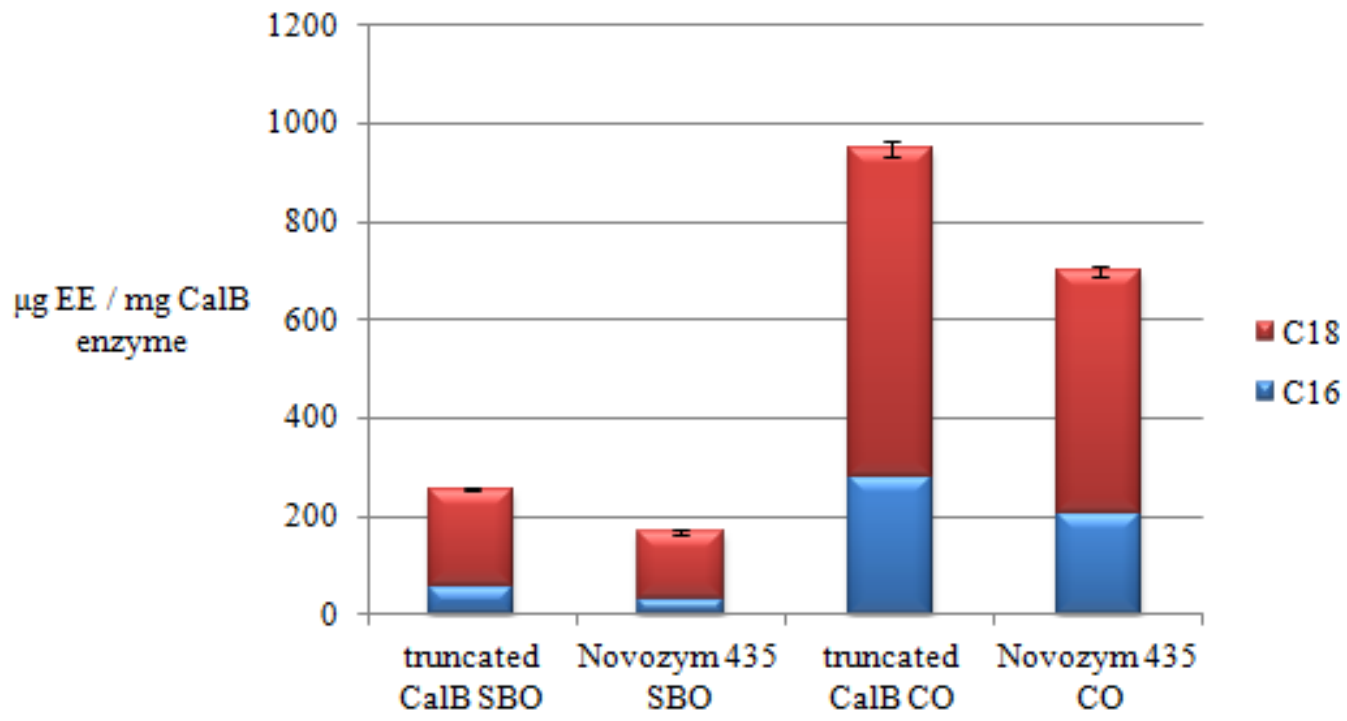

Figure 8. C16 and C18 fatty acid ethyl ester production from corn oil (CO) versus soybean oil (SBO) using resin-bound truncated CalB compared to commercial lipase, Novozym 435. Data are the calculated averages of three determinations. Error bars represent standard deviation. 


\section{Fatty Acid Ethyl Ester Production from Ethanol and Corn Oil by Resin-bound Truncated CalB in Conjunction with an Ionic Catalytic Resin}

A column containing an ionic catalytic resin was added prior and subsequent to the truncated CalB resin. The effect of an ionic resin in conjunction with a lipase resin was of interest to determine if a series of coupled resin columns could produce higher yields of fatty acid alkyl esters. The addition of an ionic resin step could prove to be useful in industrial biodiesel production settings, where crude oil is often used as a source and may contain materials that are potentially inhibiting to the catalytic cycle, or could interact with the ethyl ester product. An ionic resin could act as a filter to these potential inhibitor molecules.

Fatty acid ethyl ester production from corn oil was $53 \%$ greater when ethanol and corn oil passed through the ionic resin prior to the truncated CalB resin $(706 \mu \mathrm{g} \mathrm{EE} / \mathrm{mg}$ enzyme), compared to the reverse order (462 $\mu \mathrm{g}$ EE/mg enzyme) (Figure 9). The truncated CalB was obtained from cultures grown in rich medium. The order of the resin steps had very little effect on ethyl ester production when using truncated CalB from cultures grown in selective medium (CM Gal-Ura). Compared to the commercial lipase resin, the truncated CalB resin preceded by ionic resin produced $29 \%$ more EE/mg enzyme. 


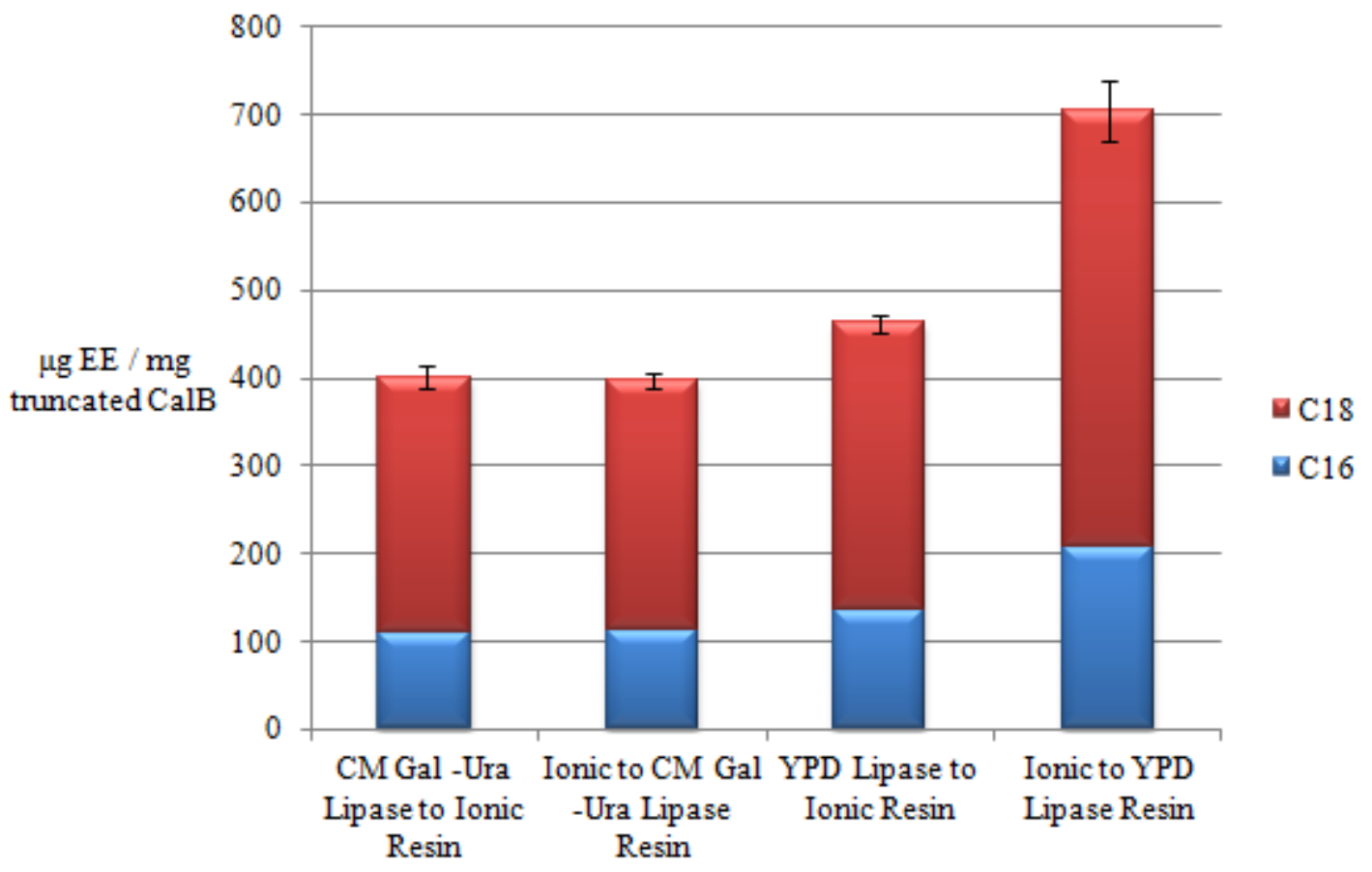

Figure 9. Addition of an ionic catalytic resin step prior to the truncated CalB resin. Data are the calculated averages of three determinations. Error bars represent standard deviation.

\section{Fatty Acid Ethyl Ester Production Catalyzed by Resin-bound Truncated CalB with Various Ratios of Ethanol to Corn Oil}

Two additional ratios, 30:1 (v/v) and 5:1 (v/v), of alcohol to oil were tested along with the 15:1 (v/v) ratios used in all previous trials. It was of interest to determine if the increase or decrease of alcohol content would inhibit or elevate fatty acid alkyl ester yield.

Fatty acid ethyl ester production catalyzed by resin-bound truncated CalB using various ratios of ethanol to corn oil is shown in Figure 10. Production of C16 and C18 ethyl esters using a ratio of 5:1 (v/v) ethanol to corn oil (2875 $\mu \mathrm{g}$ EE/mg enzyme) was 
3.7 fold higher than a ratio of 15:1 (v/v) ethanol to corn oil (774 $\mu \mathrm{g}$ EE/mg enzyme) and 8.4-fold higher than a ratio of 30:1 (v/v) ethanol to corn oil (343 $\mu \mathrm{g}$ EE/mg enzyme) when the truncated CalB resin was preceded by the ionic catalytic resin. The preference for the 5:1 ratio was also observed in the ionic resin followed by the truncated CalB resin.

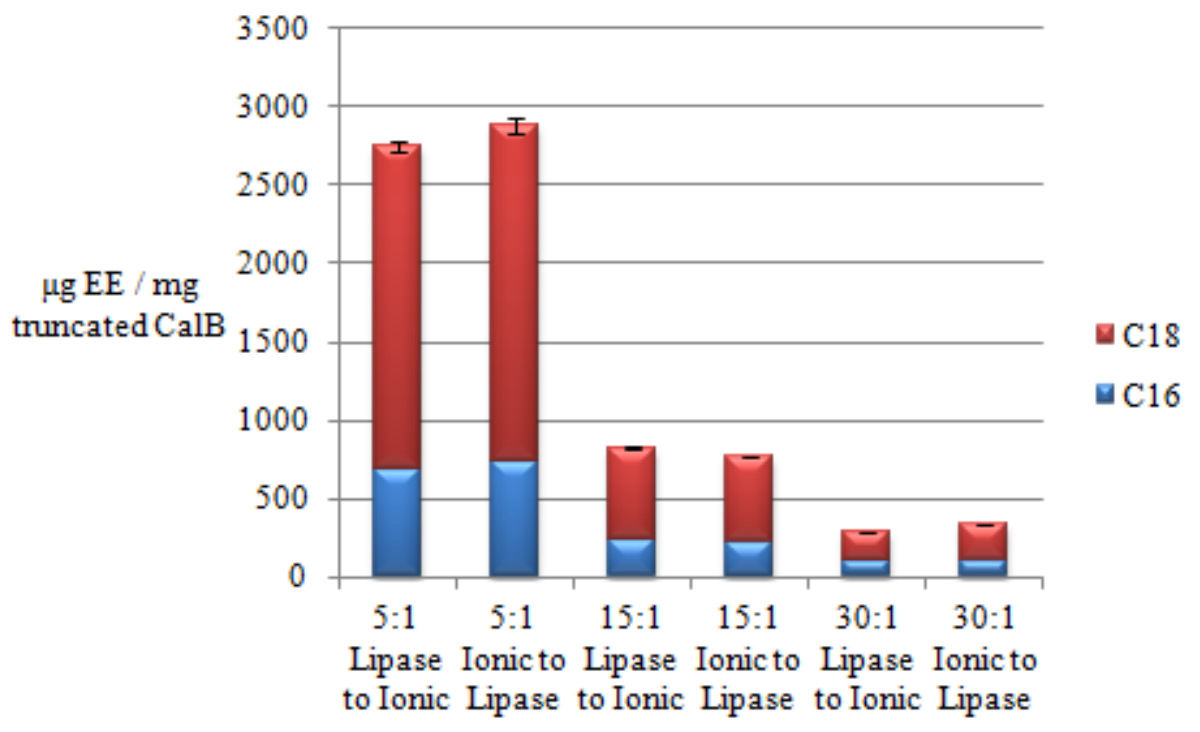

Figure 10. Production of C16 and C18 fatty acid ethyl esters using 5:1, 15:1, and 30:1 $(\mathrm{v} / \mathrm{v})$ ratios of ethanol to corn oil. Data are the calculated averages of three determinations. Error bars represent standard deviation. 


\section{Fatty Acid Alkyl Ester Production Using Resin-bound Truncated CalB with Ethanol or n-Butanol}

Production of fatty acid ethyl esters using different oil sources had previously been tested, using both corn and soybean oil. Therefore, one of the last parameters tested in the determining of alkyl ester yield catalyzed by resin-bound truncated CalB was the use of two different alcohols. In addition to ethanol, which had been used in all previous trials, n-butanol was tested to determine how different alcohol sources affect lipase catalyzed transesterification and yield of fatty acid alkyl esters.

Fatty acid alkyl ester production using resin-bound truncated CalB with 5:1 (v/v) ratio ethanol or n-butanol to corn oil is presented in Figure 11. Production of C16 and C18 butyl esters (1394 $\mu \mathrm{g} \mathrm{BE} / \mathrm{mg}$ enzyme) was $56 \%$ higher than production of $\mathrm{C} 16$ and C18 ethyl esters with corn oil (894 $\mu \mathrm{g}$ EE/mg enzyme). However, the amount of C16 alkyl esters produced by the truncated CalB enzyme was approximately the same amount with either alcohol (319 $\mu \mathrm{g} \mathrm{EE} / \mathrm{mg}$ enzyme and $355 \mu \mathrm{g} \mathrm{BE} / \mathrm{mg}$ enzyme). 


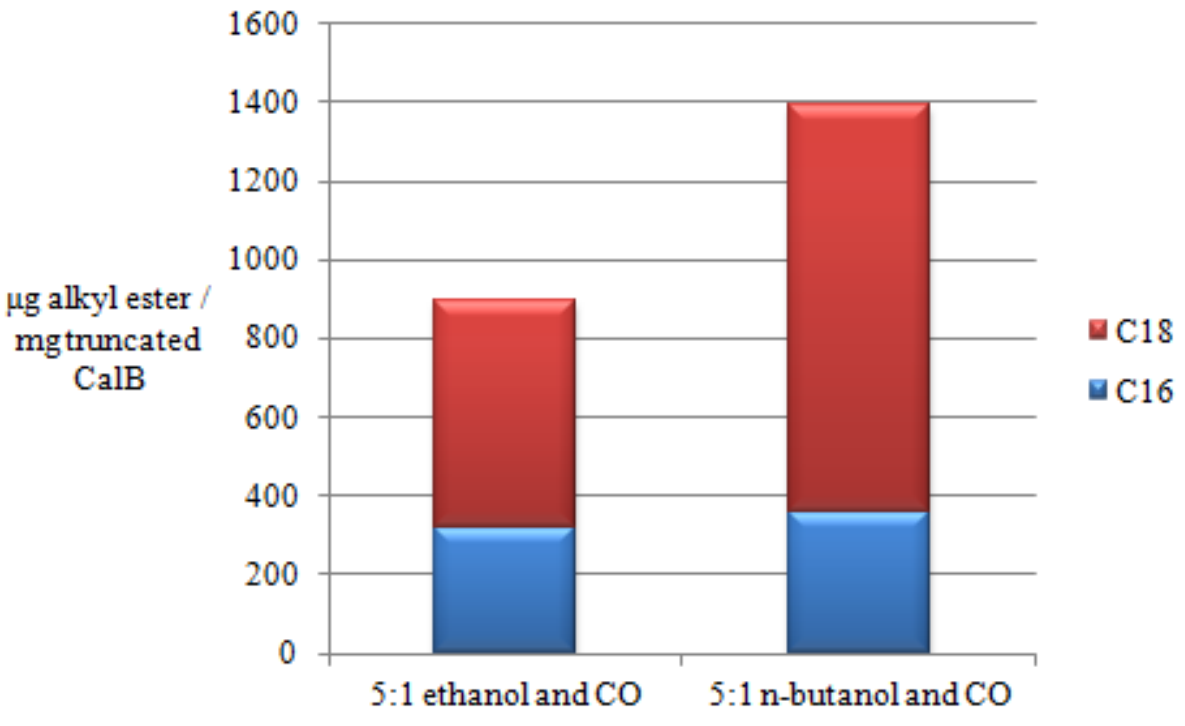

Figure 11. Fatty acid alkyl ester production using resin-bound truncated CalB with 5:1 $(\mathrm{v} / \mathrm{v})$ ratio of ethanol or $\mathrm{n}$-butanol to corn oil. Data are single point determinations. 


\section{Protein Analysis of Truncated CalB}

The Bradford (1976) protein assay was used to quantitate the amount of protein present in the $S$. cerevisiae diploid strain PJ69-4 yeast cells grown in the galactose based rich medium. A UV/Vis spectrophotometer determined the absorbance at $595 \mathrm{~nm}$ for the BioRad reagent mixed with BSA solutions of varying concentrations. A standard curve was generated by plotting the measured absorbance for each BSA solution, and a linear regression (Figure 12) was used to calculate the amount of protein.

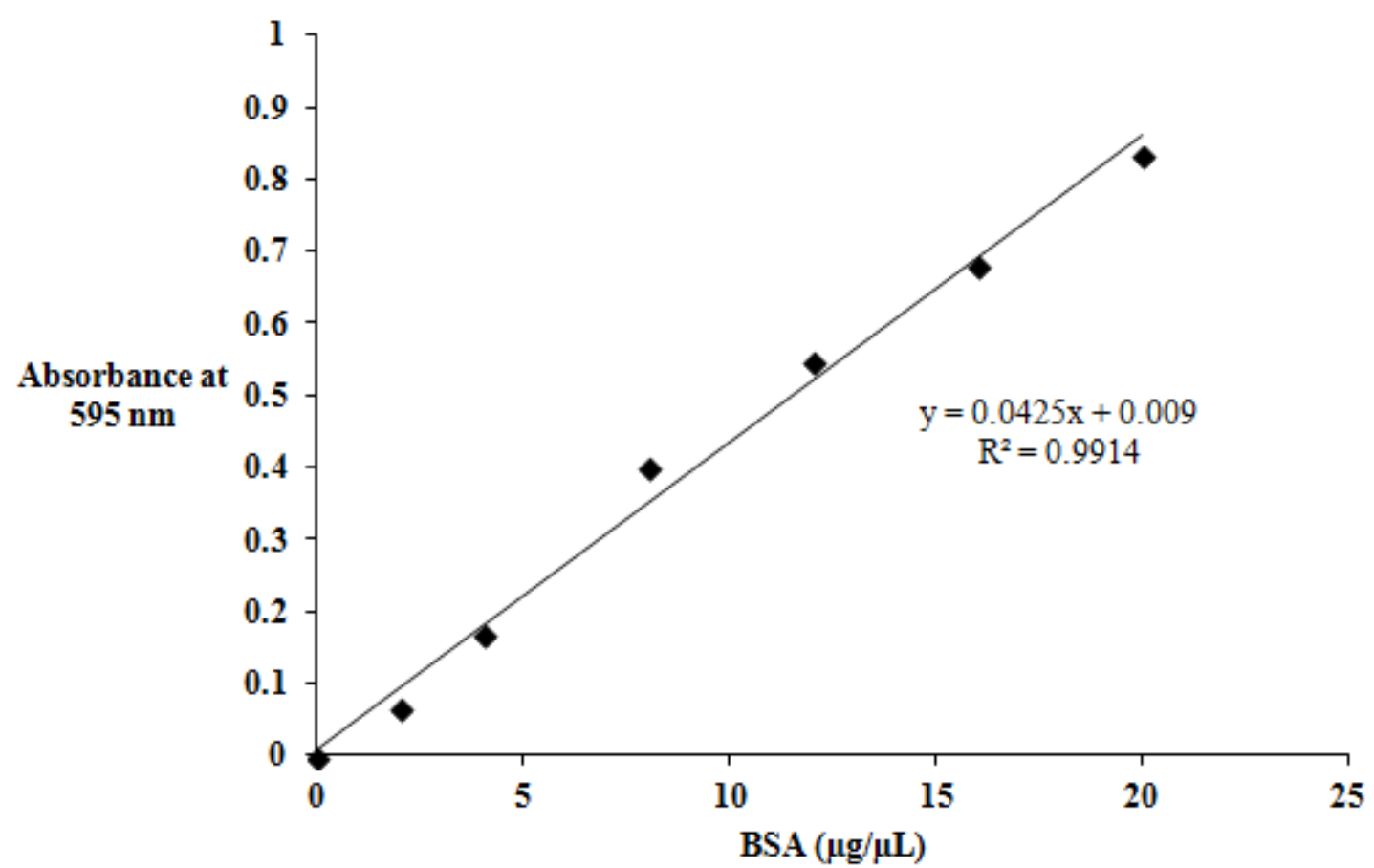

Figure 12. Bradford Assay BSA standard curve of detected absorbance at $595 \mathrm{~nm}$. 
A TALON® Metal Affinity purification column was used to isolate truncated CalB. The resin is a tetradentate chelator charged with cobalt. Since the CalB has a 6-histidine tag, it should bind to the $\mathrm{Co}^{2+}$ ion, allowing endogenous yeast proteins to pass through the column. The $200 \mathrm{mM}$ imidazole buffer displaces the histidine tag bound to the cobalt, allowing the protein of interest to elute and be harvested in a series of aliquots. The majority of the protein eluted approximately midway through the ten total samples collected (Figure 13). The protein amount per fraction was calculated from the BSA standard curve using the equation of the line.

Figure 13 shows that the presumed truncated CalB protein quickly eluted from the column around fraction 4 and gradually tapered off from its peak elution at fraction 5 until the final fraction collected, equaling ten fractions collected in total.

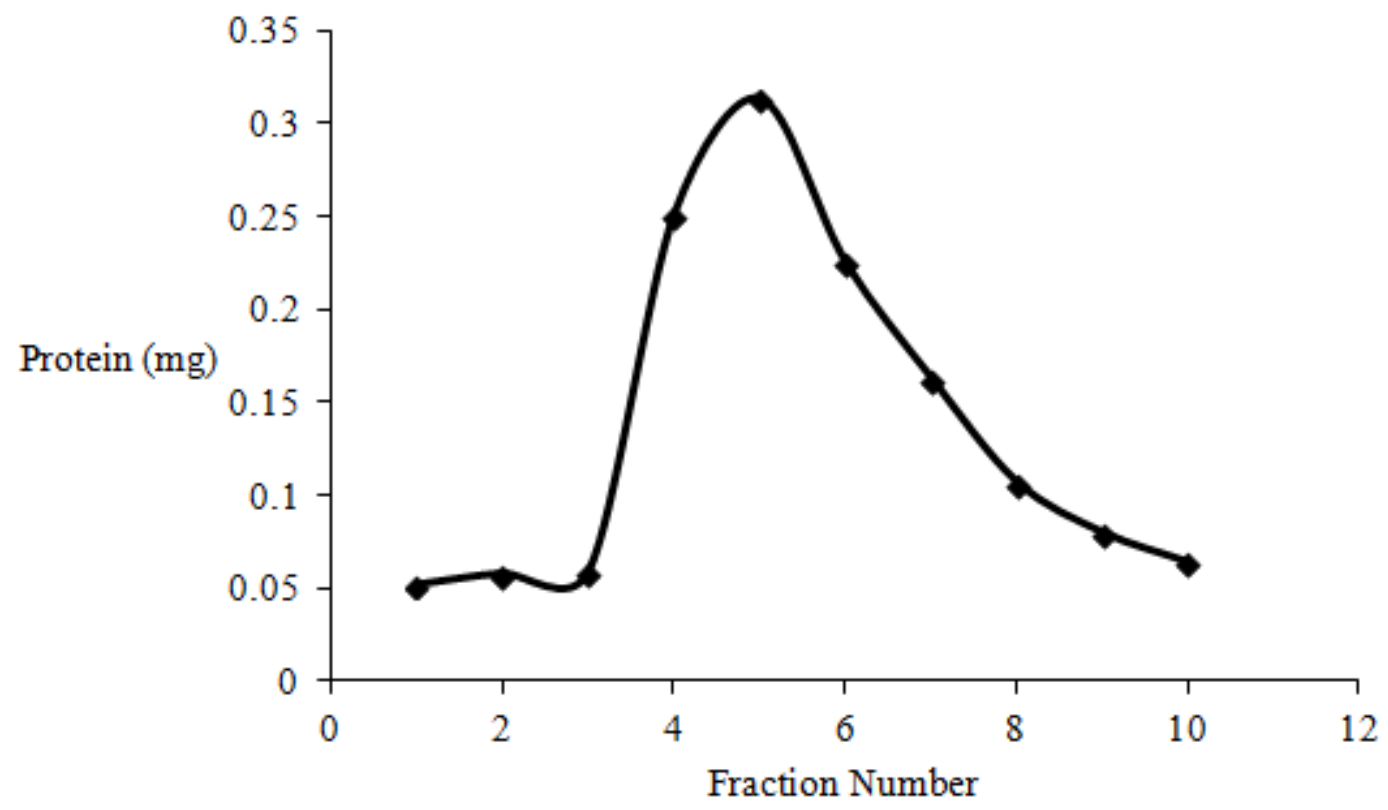

Figure 13. Amount of protein eluted $(\mathrm{mg})$ in each fraction collected from the TALON® resin column using $200 \mathrm{mM}$ imidazole, $\mathrm{pH} 7.5$ buffer and collecting $1 \mathrm{~mL}$ per fraction. 


\section{SDS-PAGE Analysis of Truncated CalB}

To determine if the truncated CalB was extracted and isolated from the lysed yeast cells, the purified fraction samples containing the highest amount of protein were analyzed by SDS-PAGE. A prestained molecular weight standard (phosphorylase b, $97.4 \mathrm{kDa}$; serum albumin, $66.2 \mathrm{kDa}$; ovalbumin, $45.0 \mathrm{kDa}$; carbonic anhydrase, $31.0 \mathrm{kDa}$; trypsin inhibitor, $21.5 \mathrm{kDa}$; lysozyme, $14.4 \mathrm{kDa}$ ) was added to the first well of the polyacrylamide gel to use as a reference marker to estimate the molecular weight of the visible protein bands. The theoretical molecular weight for the truncated CalB sequence most likely being expressed is $30 \mathrm{kDa}$, slightly less than the molecular weight of Candida antarctica lipase B, $33 \mathrm{kDa}$ (Uppenberg et al. 1994b), but with the inclusion of the artificial methionine $(0.1 \mathrm{kDa}), 29$ amino acids from the attB recombination site (3.1 kDa), and a 6 histidine tag from the original PCR assembly $(0.6 \mathrm{kDa})$, the overall detectable protein is equal to $33.8 \mathrm{kDa}$ in size.

Throughout all fractions collected from the TALON® resin column, there is a definite Coomassie stained band at approximately $50 \mathrm{kDa}$, appearing most clearly in lanes 12-14 shown in Figure 14. Additionally, there is a much fainter, but still noticeable band present at approximately $28 \mathrm{kDa}$ beginning in lane 13 (fraction 5) and continually present in each lane of the remaining fractions collected. Neither of these detected bands corresponds to the theoretical molecular weight of the truncated CalB, nor the reported literature value of the wild type. However, the possibility of a dimerized version of the truncated CalB protein was considered as the $50 \mathrm{kDa}$ band is more approximate to the size of two individual truncated CalB proteins. 


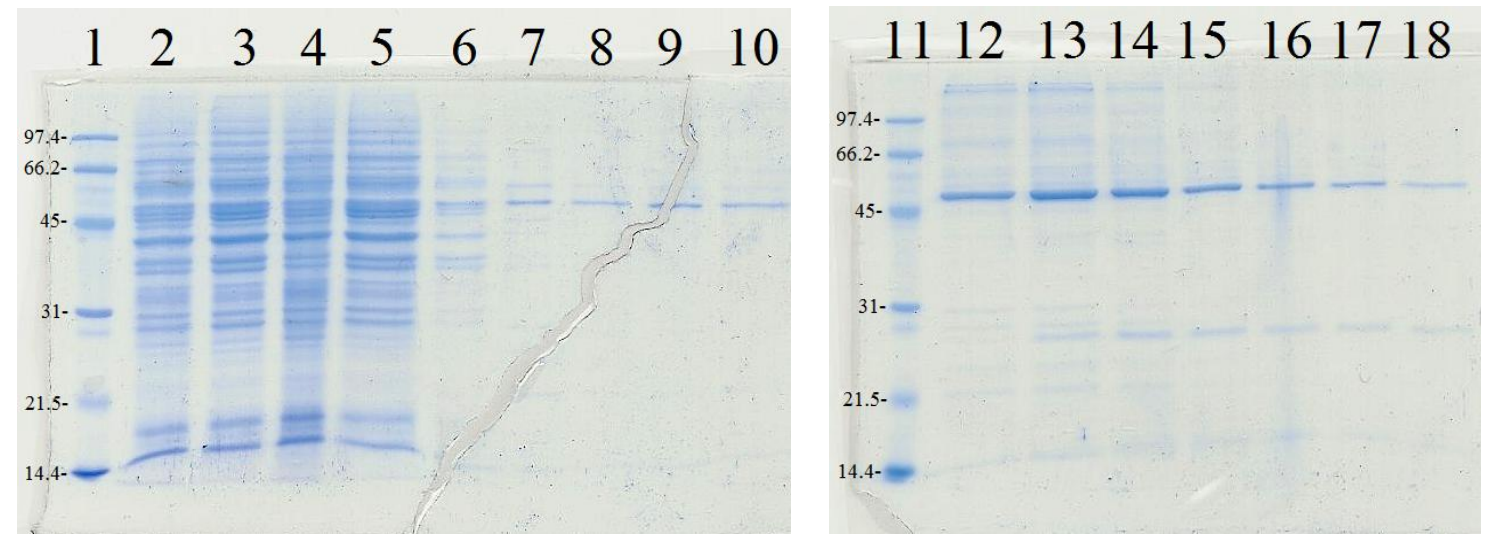

Figure 14. Coomassie blue staining of the polyacrylamide gel containing the samples collected throughout the purification process.

$\begin{array}{cc}\text { Lane } & \text { Component } \\ 1 & \text { Molecular Weight Standard (kDa) } \\ 2 & \text { Yeast Cell Crude Extract } \\ 3 & \text { Cell Supernatant } \\ 4 & \text { Cell Pellet } \\ 5 & \text { Flow Through } \\ 6 & \text { Buffer Wash } \\ 7 & \text { Imidazole Buffer } \\ 8 & \text { Purified Fraction } 1^{*} \\ 9 & \text { Purified Fraction } 2^{*} \\ 10 & \text { Purified Fraction 3* } \\ 11 & \text { Molecular Weight Standard (kDa) } \\ 12 & \text { Purified Fraction } 4 * \\ 13 & \text { Purified Fraction 5* } \\ 14 & \text { Purified Fraction 6* } \\ 15 & \text { Purified Fraction 7* } \\ 16 & \text { Purified Fraction } 8^{*} \\ 17 & \text { Purified Fraction 9* } \\ 18 & \text { Purified Fraction } 10^{*} \\ & \end{array}$

*Fractions collected from $200 \mathrm{mM}$ imidazole used to elute protein from TALON® resin. 
Since the protein of interest contains a 6-histidine tag on the amino terminus, a Western blot analysis (Figure 15) was performed with the same samples presented in the Coomassie stain data to determine if a single protein band could be detected closer to the theoretical molecular weight of the truncated CalB.

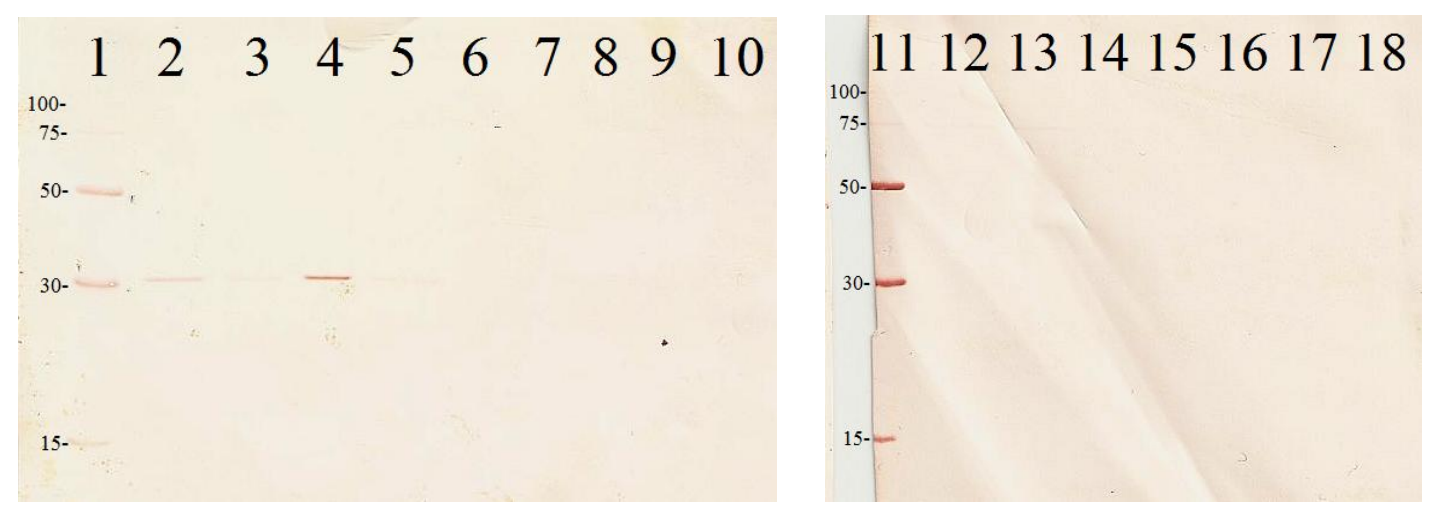

Figure 15. Western blot of the samples collected throughout the protein purification process.

A single red band was detected in lanes 2-4, which included the yeast crude extract, cell supernatant, and cell pellet. Lane 4 (cell pellet) presented the clearest visible red band at approximately $33 \mathrm{kDa}$ in relation to the His-tag marker. A slightly fainter red band is present in lane 2 (crude extract) and a much fainter band is slightly visible in lane 3 (cell supernatant), both approximately $33 \mathrm{kDa}$. No bands were visibly detectable in the purified fraction samples, therefore from these data it was concluded that perhaps the majority of the truncated CalB had not been extracted from the cell pellet. 


\section{Effects of Addition of a Reducing Agent}

To assess the possibility that a dimerized version of the truncated CalB was the detectable Coomassie stained protein band visible at approximately $50 \mathrm{kDa}$, addition of the reducing agent $\beta$-mercaptoethanol (BME) to a $2 X$ SDS-PAGE loading buffer of the prepared samples was implemented. Samples of purified fractions containing the highest concentration of protein measured were diluted with 2 X SDS loading buffer and BME. Additionally, samples of the same purified fractions were prepared in the standard $4 \mathrm{X}$ SDS loading buffer as controls. Visible Coomassie stained protein bands were again detectable in the purified fraction samples, represented in lanes 1 and 8-10 in Figure 16. Lanes 1 and 10 contained the samples diluted in BME, and only a single prominent band was detected at approximately $50 \mathrm{kDa}$. Lanes 8 and 9, containing the samples prepared in the standard 4X SDS loading buffer retained the same visible band at approximately $50 \mathrm{kDa}$ seen previously in Figure 12. Comparing the samples prepared in BME to those of the standard $4 \mathrm{X}$ SDS loading buffer sample, the band at $50 \mathrm{kDa}$ was still present and slightly fainter in those prepared in BME. No other protein bands were detectable in lanes 1 and 10. 


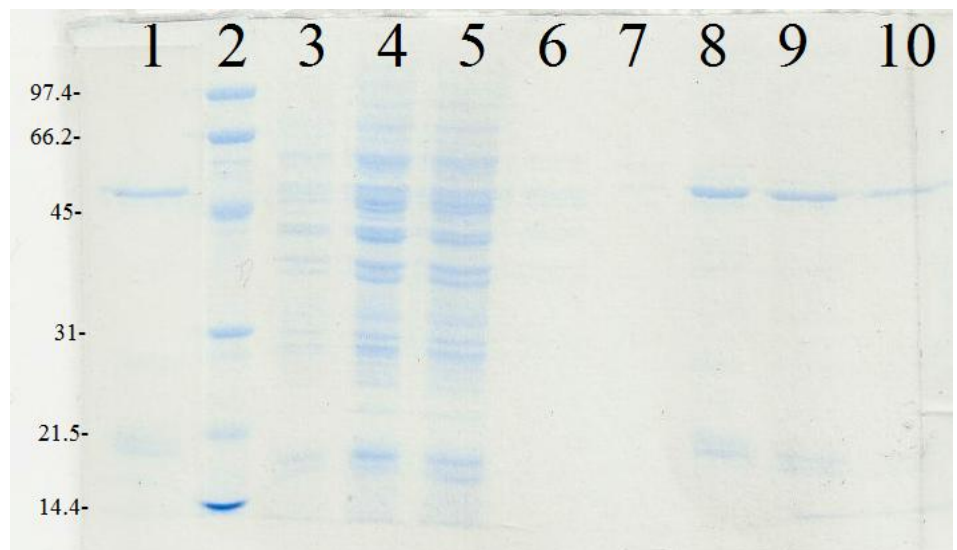

Figure 16. Coomassie blue staining of the purified samples prepared in SDS-PAGE loading buffer containing $2 \mathrm{X} \beta$-mercaptoethanol (BME) and $4 \mathrm{X}$ standard loading buffer.

$\underline{\text { Lane }}$ $\underline{\text { Components }}$

Fraction Sample 1 with 2X SDS Loading Buffer + BME Molecular Weight Standard (kDa)

Yeast Cell Crude Extract

Cell Supernatant

Flow Through

Buffer Wash

Imidazole Buffer

Fraction Sample 1 with 4X SDS Loading Buffer

Fraction Sample 2 with 4X SDS Loading Buffer

Fraction Sample 2 with 2X SDS Loading Buffer + BME 


\section{Effects of Addition of Protein Detergents}

Several detergents were used to further extract protein from the pellet sample.

Pelleted cultures expressing both the truncated CalB and the recombinant full-length wild type were resuspended in a $1 \%$ solution of NP-40. After SDS-PAGE, a Coomassie stain (Figure 17) was obtained, and several protein bands were observed in all sample lanes.

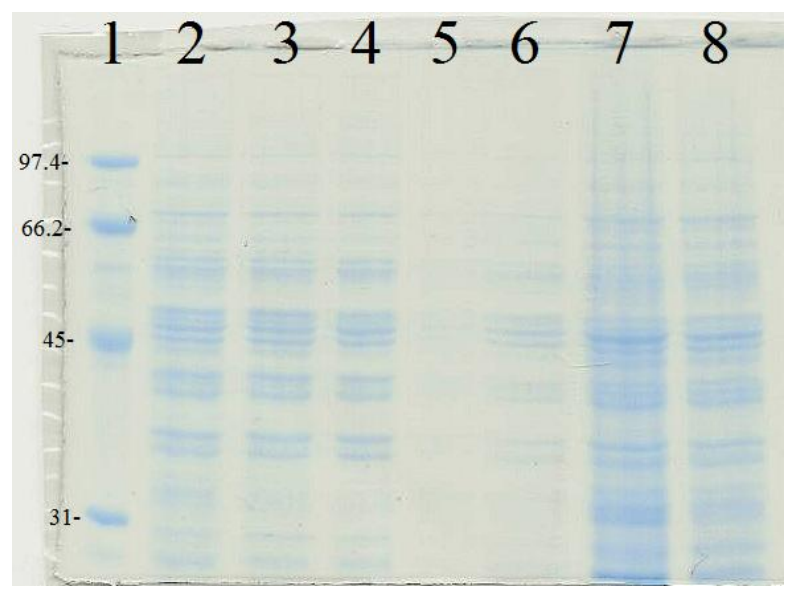

Figure 17. Coomassie blue stained SDS-PAGE showing samples taken from truncated and full-length CalB lysate pellet resuspended in 1\% NP-40 in $50 \mathrm{mM}$ Tris, $100 \mathrm{mM}$ $\mathrm{NaCl}, \mathrm{pH} 7.5$ buffer.

$\begin{array}{cc}\underline{\text { Lane }} & \underline{\text { Components }} \\ 1 & \text { Molecular Weight Standards (kDa) } \\ 2 & \text { Full-length CalB Yeast Cell Crude Extract } \\ 3 & \text { Full-length CalB Cell Supernatant } \\ 4 & \text { Truncated CalB Cell Supernatant } \\ 5 & \text { Full-length CalB Cell Supernatant with 1\% NP-40 } \\ 6 & \text { Truncated CalB Cell Supernatant with 1\% NP-40 } \\ 7 & \text { Full-length CalB Cell Pellet after 1\% NP-40 } \\ 8 & \text { Truncated CalB Cell Pellet after 1\% NP-40 }\end{array}$


The scenario was repeated, but with increasing the amount of NP-40 to $10 \%$, with the resulting Coomassie stained gel (Figure 18) showing no significant change from the previous attempt. No specific protein bands were prominent among the several bands visible in either of the samples resuspended in $1 \%$ or $10 \%$ NP-40 solutions.

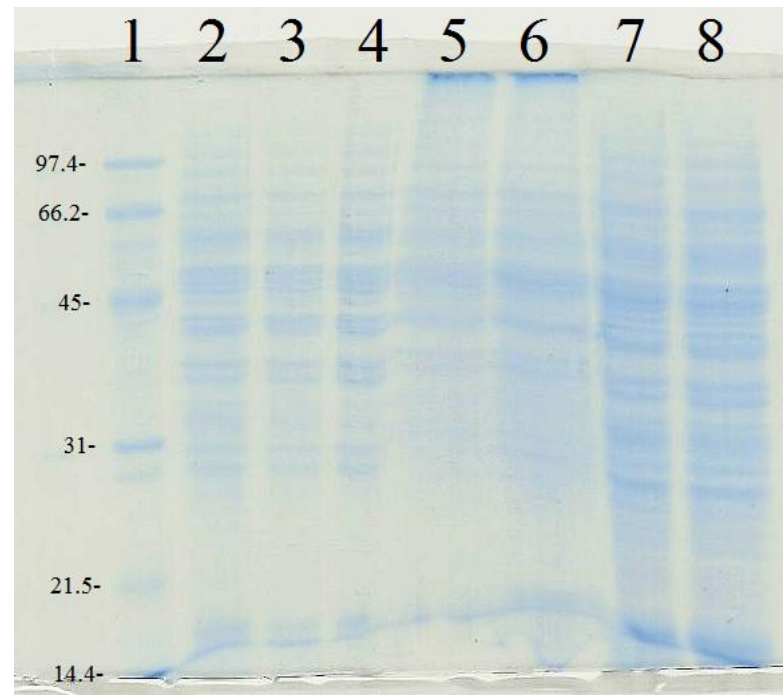

Figure 18. Coomassie blue stain showing samples taken from truncated and full-length CalB lysate pellet resuspended in 10\% NP-40 in $50 \mathrm{mM}$ Tris, $100 \mathrm{mM} \mathrm{NaCl}$, pH 7.5 buffer.

$\underline{\text { Lane }}$

\section{Components}

Molecular Weight Standards (kDa)

Full-length CalB Yeast Cell Crude Extract

Full-length CalB Cell Supernatant

Truncated CalB Cell Supernatant

Full-length CalB Cell Supernatant with 10\% NP-40

Truncated CalB Cell Supernatant with 10\% NP-40

Full-length CalB Cell Pellet after 10\% NP-40

Truncated CalB Cell Pellet after 10\% NP-40 
The detergents Triton X-100 and octyl- $\beta$-D-glucopyranoside (OGP) were tested concurrently on both the truncated and full-length versions of CalB. Pelleted cultures expressing both CalB variations were separately resuspended in 10\% Triton X-100 and 1\% OGP, followed with SDS-PAGE and Western blot analysis (Figures 19, 20).

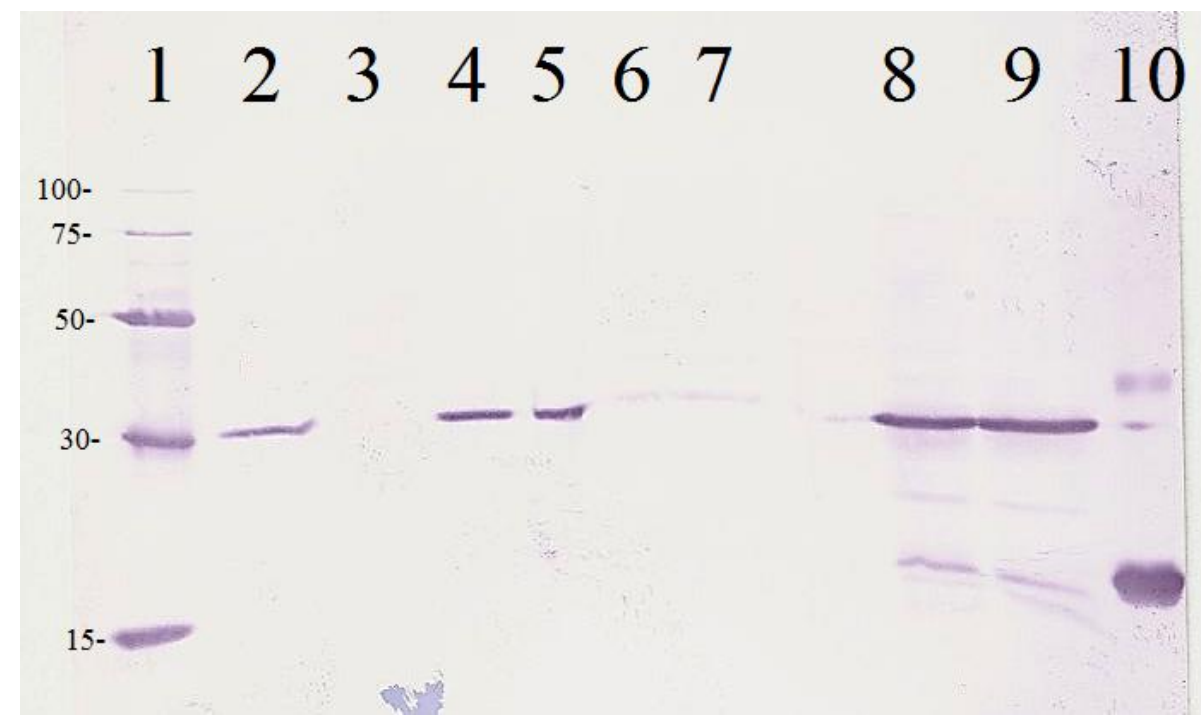

Figure 19. Western blot of samples from full-length CalB lysate pellet resuspended in $10 \%$ Triton X-100 and 1\% OGP in $50 \mathrm{mM}$ Tris, $100 \mathrm{mM} \mathrm{NaCl}, \mathrm{pH} 7.5$ buffer.

\section{$\underline{\text { Lane }}$}

1

2

3

4

5

6

7

8

9

10
Components

His-tag Molecular Weight Standards (kDa) Yeast Cell Crude Extract Cell Supernatant

Cell Pellet with 10\% TX-100 Cell Pellet with $1 \%$ OGP Cell Supernatant with $10 \%$ TX-100

Cell Supernatant with $1 \%$ OGP

Cell Pellet from 10\% TX-100

Cell Pellet from 1\% OGP

Reference Protein 


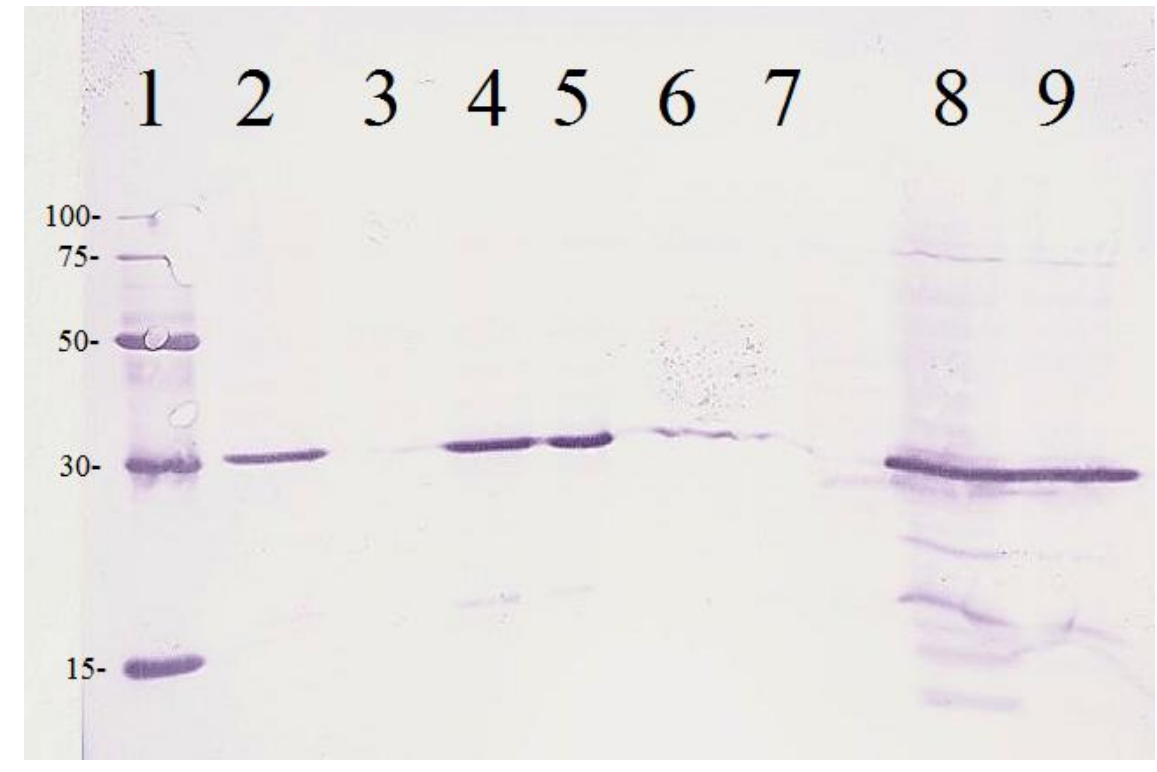

Figure 20. Western blot of truncated CalB lysate pellet resuspended in $10 \%$ Triton X-100 and $1 \%$ OGP in $50 \mathrm{mM}$ Tris, $100 \mathrm{mM} \mathrm{NaCl}$, pH 7.5 buffer.

\section{$\underline{\text { Lane }}$}

1

2

3

4

5

6

7

8

9

\section{$\underline{\text { Components }}$}

His-tag Molecular Weight Standards (kDa)

Yeast Cell Crude Extract

Cell Supernatant

Cell Pellet with $10 \%$ TX-100

Cell Pellet with $1 \%$ OGP

Cell Supernatant with $10 \%$ TX-100

Cell Supernatant with $1 \%$ OGP

Cell Pellet from 10\% TX-100

Cell Pellet from 1\% OGP 
In both the full-length and truncated CalB samples, protein bands were still predominantly visible at approximately $33.8 \mathrm{kDa}$ in the yeast cell crude extract (lane 2, both Figures 19 and 20) the pellet samples suspended in the detergent solutions (lanes 4, 5, both Figures 19 and 20), and the pellet samples again after centrifugation and decantation of the supernatant, resuspended in $50 \mathrm{mM}$ Tris, $100 \mathrm{mM} \mathrm{NaCl}, \mathrm{pH} 7.5$ buffer (lanes 8, 9, both Figures 19 and 20). However, a band was visible at this length in the cell supernatant samples lanes 6 and 7 in both Figure 19 and 20, although much fainter in appearance than those observed in the crude extract and pellet samples. Relatively no difference was observed between the appearance of the protein bands in the full-length CalB samples and the truncated CalB counterparts, except for the truncated CalB cell supernatant with Triton X-100 sample (lane 6, Figure 20) which has a noticeably darker band visible at the approximate $33.8 \mathrm{kDa}$ length in comparison to the truncated CalB cell supernatant sample with OGP (lane 7, Figure 20) and both full-length CalB cell supernatant samples (lane 6 and 7, Figure 19). 


\section{Effect of Increased Pressure During Cell Lysis}

The internal cell pressure of the French Press apparatus was initially set at 15,000 psi, but according to the European Molecular Biology Laboratory (EMBL) proper lysis of yeast cells occurs at around 30,000 psi. After increasing the cell pressure and repeating the purification process, a Western blot (Figure 21) was obtained.

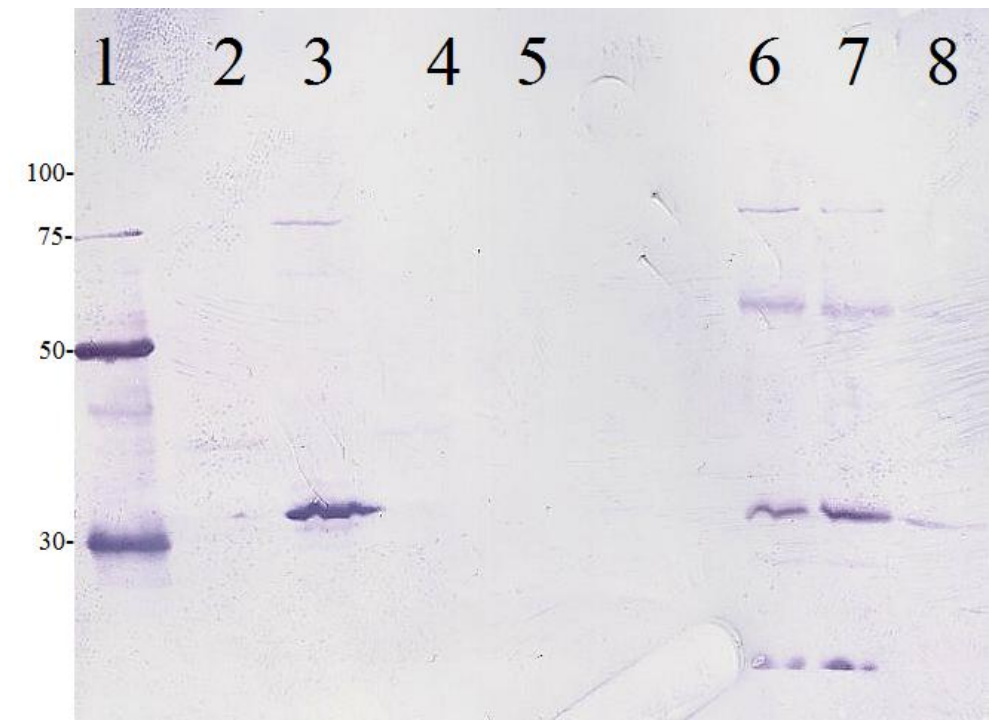

Figure 21. Western blot of purification samples after yeast cell lysis at increased pressure of 30,000 psi.

$\begin{array}{cc}\underline{\text { Lane }} & \text { Components } \\ 1 & \text { His-tag Molecular Weight Standards (kDa) } \\ 2 & \text { Yeast Cell Crude Extract } \\ 3 & \text { Cell Supernatant } \\ 4 & \text { Cell Pellet } \\ 5 & \text { Flow Through } \\ 6 & \text { Purified Fraction } 3 \\ 7 & \text { Purified Fraction } 4 \\ 8 & \text { Purified Fraction } 8\end{array}$


Increasing the internal cell pressure appeared to have some positive effect on the amount of protein extracted. A visible protein band at approximately $33.8 \mathrm{kDa}$ appeared in lane 3 , corresponding to the cell supernatant, of the Western blot analysis presented in Figure 21. The cell pellet sample (lane 4) had no visible protein bands. The purified fraction samples with the highest detected protein concentration (lane 6 and 7) had visible bands at $33.8 \mathrm{kDa}$. Additionally, bands visible at approximately $80 \mathrm{kDa}, 55 \mathrm{kDa}$, and $15 \mathrm{kDa}$ were also observed in these purified samples, indicating that other His-tagged proteins were present. The purified fraction sample with a lower protein concentration (lane 8) also had a band at $33.8 \mathrm{kDa}$, although much fainter in appearance than observed in lanes 6 and 7 . 


\section{Determination of Kinetic Activity}

Using the method of Blank et al. (2006), varying concentrations of the substrate molecule, para-nitrophenyl butyrate (p-NPB), ranging from 40-1000 $\mu \mathrm{M}$, were initially used to determine the specific activity of the truncated CalB enzyme. After calculating the reaction velocity, $\mathrm{V}_{0}$, of the enzyme with each substrate concentration, the data were fitted with the Michaelis-Menten equation to determine the kinetic constants $V_{\max }$, the maximal reaction rate, and $\mathrm{K}_{\mathrm{m}}$, the substrate concentration at half the maximal reaction rate (Figure 22). However, this range of concentrations did not produce a typical Michaelis-Menten curve, which demonstrates a leveling off of the reaction rate as concentration of substrate increases.

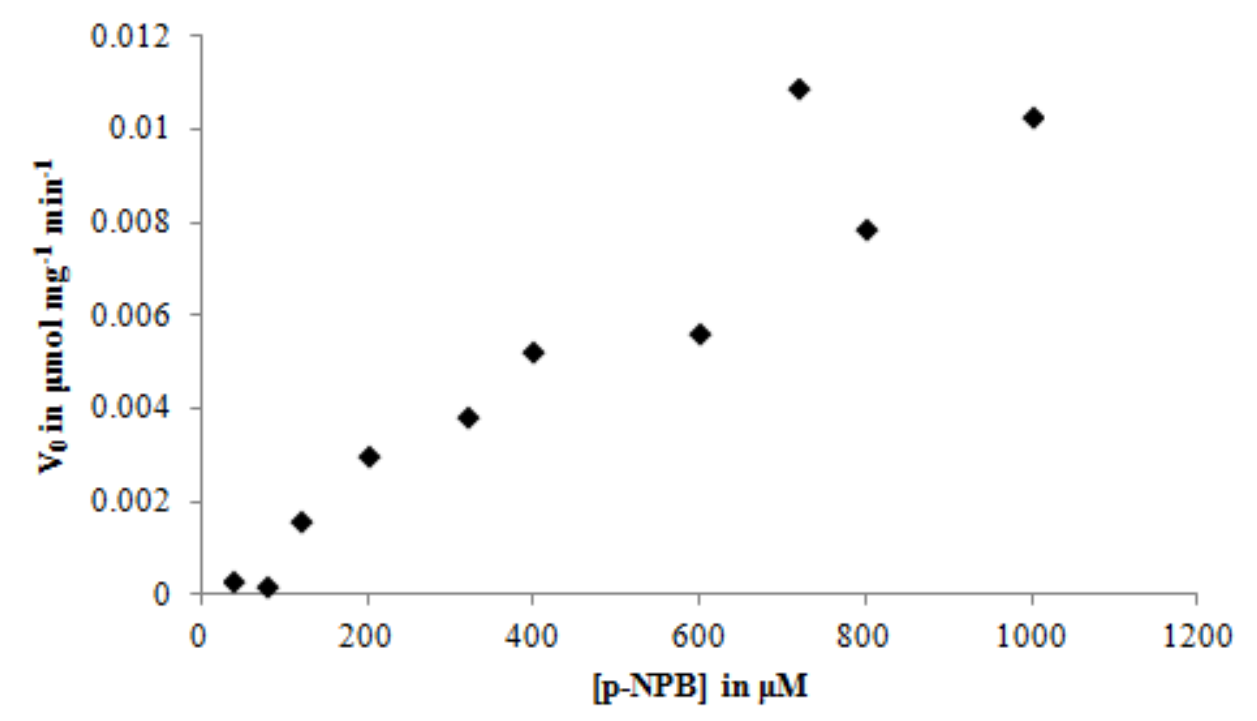

Figure 22. Michaelis-Menten plot for the substrate p-NPB ranging from $40-1000 \mu \mathrm{M}$ and the truncated CalB enzyme using the method of Blank et al. (2006). 
The resulting plot demonstrated a linear relationship with the varying concentration of p-NPB to the truncated CalB, indicating the $V_{\max }$ had not yet been attained. Therefore, additional concentrations of the substrate solution ranging from $2000-6000 \mu \mathrm{M}$ were analyzed in this assay. The resulting reaction rates that were determined for the higher concentrations were incorporated into the existing Michaelis-Menten plot (Figure 23), producing a curve more typical of an enzyme reaction leveling off upon reaching the maximal rate at higher substrate concentrations.

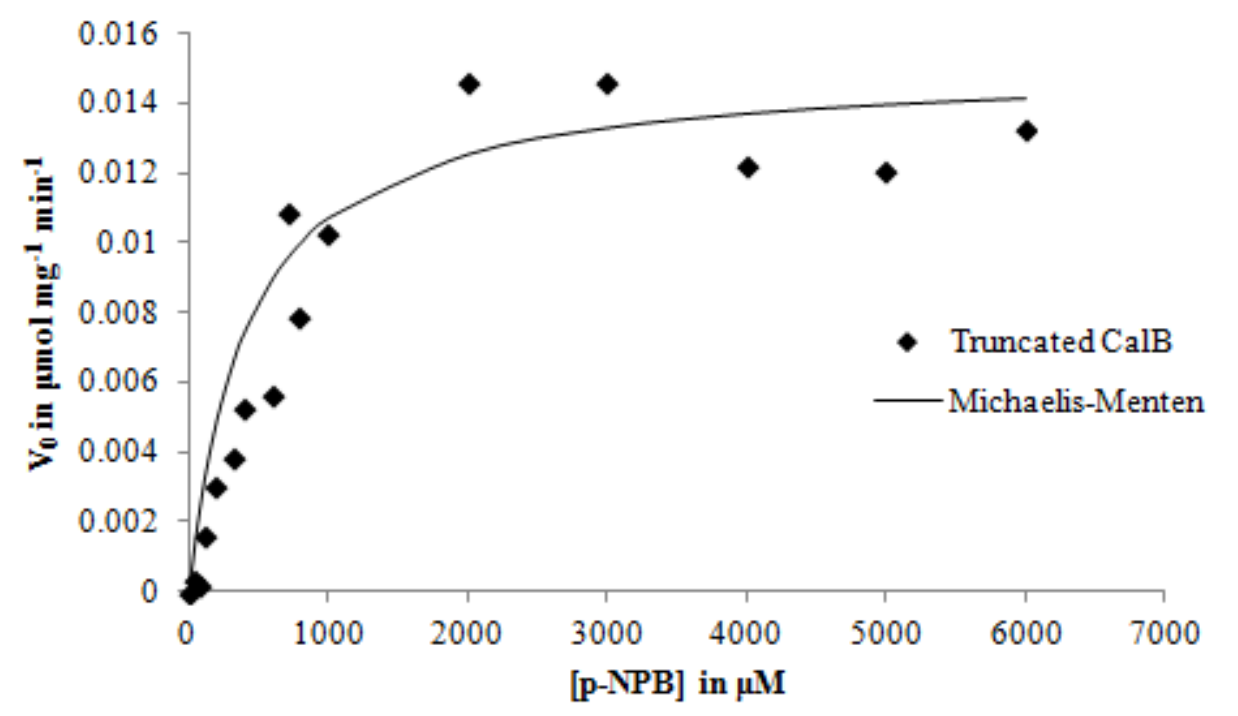

Figure 23. Michaelis-Menten plot for the substrate p-NPB ranging from $40-6000 \mu \mathrm{M}$ and the truncated CalB enzyme using the method of Blank et al. (2006).

The values for $\mathrm{V}_{\max }$ and $\mathrm{K}_{\mathrm{m}}$ were determined by performing a non-linear regression analysis of the calculated reaction rates. The value calculated for $\mathrm{V}_{\max }$ was $0.0151 \mu \mathrm{mol} \mathrm{mg}{ }^{-1} \mathrm{~min}^{-1}$, with a $\mathrm{K}_{\mathrm{m}}$ of $410 \mu \mathrm{M}$. The study performed by Blank et al. (2006) reported a $\mathrm{V}_{\max }$ value of $237 \mu \mathrm{mol} \mathrm{mg} \mathrm{min}^{-1}$ with a $\mathrm{K}_{\mathrm{m}}$ of $5492 \mu \mathrm{M}$, both considerably higher than the values measured for the truncated CalB. 
The method of Martinelle et al. (1995) was used to determine the specific activity for both the truncated and full-length CalB enzyme. The substrate p-NPB was also used for this method with concentrations ranging from $40-20000 \mu \mathrm{M}$. The calculated reaction velocities for the truncated CalB were plotted against the respective substrate concentrations, resulting in the type of curve expected for the Michaelis-Menten model (Figure 24), with the rate of reaction noticeably leveling off at the higher concentrations of substrate.

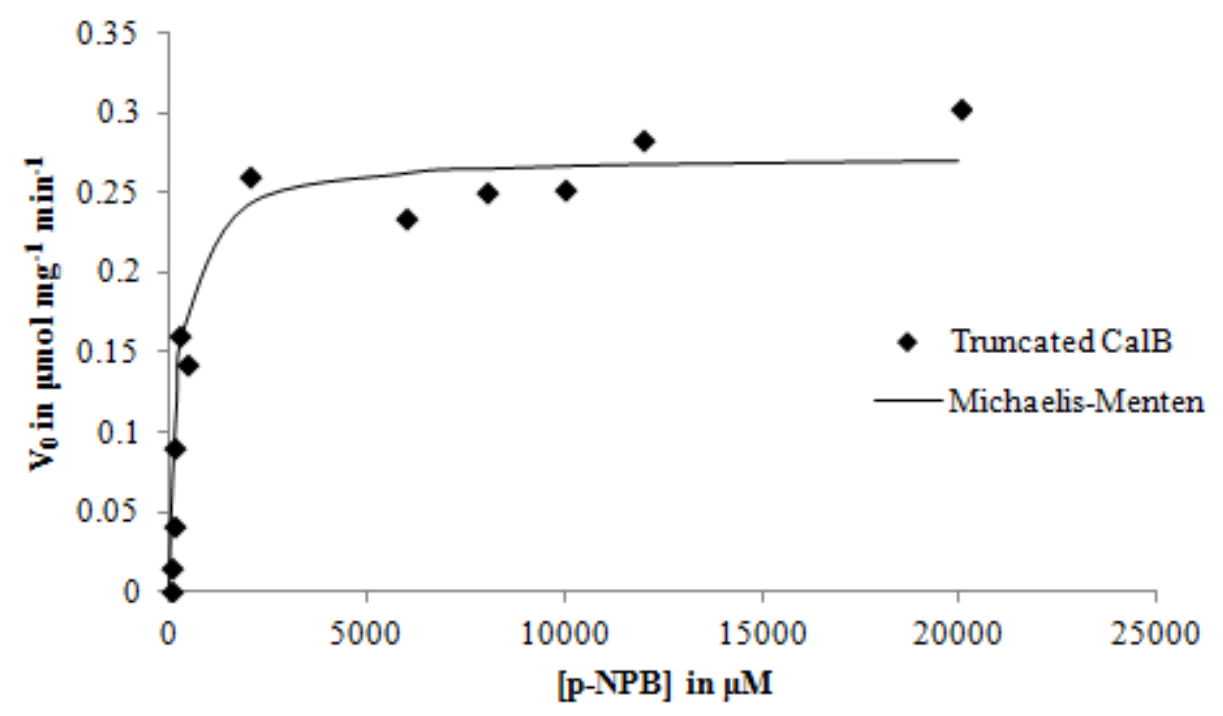

Figure 24. Michaelis-Menten plot for the substrate p-NPB ranging from 40-20000 $\mu \mathrm{M}$ and the truncated CalB enzyme using the method of Martinelle et al. (1995).

A non-linear regression of the data was performed, determining the value for $\mathrm{V}_{\max }$ to be $0.274 \mu \mathrm{mol} \mathrm{mg}{ }^{-1} \mathrm{~min}^{-1}$, with a $\mathrm{K}_{\mathrm{m}}$ of $258 \mu \mathrm{M}$ for the truncated CalB enzyme. 
The calculated reaction velocities for the full-length CalB were plotted against the respective substrate concentrations, also resulting in an observable leveling off of the rate of reaction at the higher concentrations of substrate, fitting the Michaelis-Menten model (Figure 25).

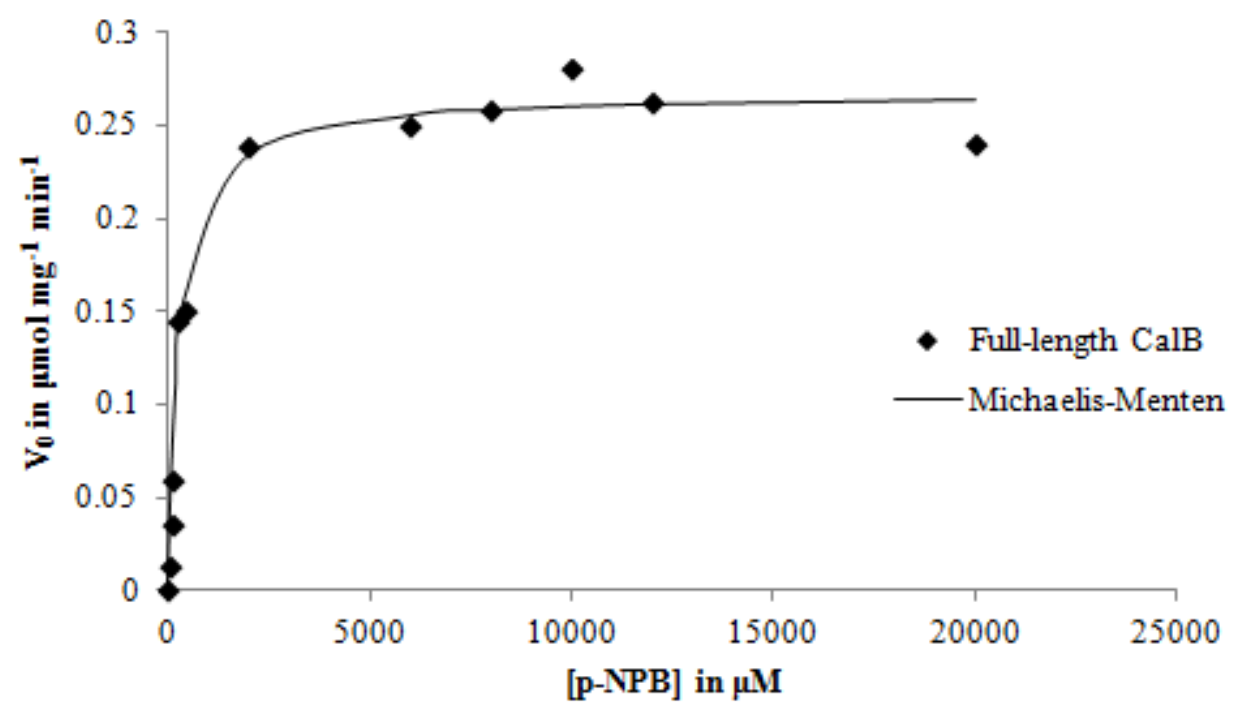

Figure 25. Michaelis-Menten plot for the substrate p-NPB ranging from $40-20000 \mu \mathrm{M}$ and the full-length CalB enzyme using the method of Martinelle et al. (1995).

A non-linear regression of the data determined the value for $\mathrm{V}_{\max }$ to be $0.267 \mu \mathrm{mol} \mathrm{mg}{ }^{-1} \mathrm{~min}^{-1}$, with a $\mathrm{K}_{\mathrm{m}}$ of $287 \mu \mathrm{M}$ for the full-length CalB enzyme. The study performed by Martinelle et al. (1995) reported a $V_{\max }$ value of $31.0 \mu \mathrm{mol} \mathrm{mg}^{-1} \mathrm{~min}^{-1}$, considerably higher than the values measured for the truncated and full-length CalB. Table 1 summarizes the calculated kinetic constants using the two enzyme assay methods. 
Table 1

Summary of Kinetic Constants Determined for Truncated and Full-length CalB

\begin{tabular}{llllll}
\hline Method & Enzyme & $\begin{array}{l}\text { Concentration } \\
(\mu \mathrm{g} / \mu \mathrm{L})\end{array}$ & $\begin{array}{l}\mathrm{V}_{\max } \\
\left(\mu \mathrm{mol} \mathrm{mg} \mathrm{min}^{-1}\right)\end{array}$ & $\begin{array}{l}\mathrm{K}_{\mathrm{m}} \\
(\mu \mathrm{M})\end{array}$ & $\mathrm{V}_{\max } / \mathrm{K}_{\mathrm{m}}$ \\
\hline Blank & Literature CalB & $\mathrm{N} / \mathrm{A}$ & 237 & 5492 & $4.32 \times 10^{-2}$ \\
& Truncated CalB & 0.32 & 0.0151 & 410 & $3.68 \times 10^{-5}$ \\
& & & & \\
\multirow{3}{*}{ Martinelle } & Literature CalB & $\mathrm{N} / \mathrm{A}$ & 31.0 & $\mathrm{~N} / \mathrm{A}$ & $\mathrm{N} / \mathrm{A}$ \\
& Truncated CalB & 0.12 & 0.274 & 258 & $1.06 \times 10^{-3}$ \\
& Full-length CalB & 0.030 & 0.267 & 287 & $9.30 \times 10^{-4}$ \\
\hline
\end{tabular}

The kinetic constants of the truncated and full-length CalB determined from the method of Martinelle et al. (1995) were similar in value. The catalytic efficiency $\left(\mathrm{V}_{\max } / \mathrm{K}_{\mathrm{m}}\right)$ of the truncated CalB is slightly greater than the full-length CalB. However, the concentration of truncated CalB was $75 \%$ greater than the full-length version, therefore a considerably less amount of the full-length CalB was almost as catalytically active as the truncated CalB. 


\section{CHAPTER IV}

\section{CONCLUSIONS AND FUTURE WORK}

\section{Expression of the Truncated CalB}

Western blot analysis of the synthetic Candida antarctica lipase B sequence previously constructed (Hughes et al. 2011) containing six artificial ATG start codons determined that five of the six possible truncated CalB proteins were able to be expressed in yeast grown in galactose medium, with four of these five proteins containing the most distinctive active site feature, the residues Asp187-His224-Ser105, collectively known as the catalytic triad. Only the protein expressed at $33.8 \mathrm{kDa}$, the longest ORF of the five sequences expressed, contained the other key structural features of the lipase active site; the oxyanion hole (Gly39 and Thr40), the hydrophobic acyl-substrate pocket (Leu140, Leu144, Val 190, Val154), and the alcohol-binding pocket (Thr42, Ser47, and Trp104). Deletion of the first 34 residues in the CalB sequence does not appear to negatively impact expression of the ORF containing the first artificial ATG codon. Studies have shown that in some yeast strains, particularly Saccharomyces cerevisiae, 5' end-mediated translation is preferred over internal initiation, especially in laboratory conditions (Thompson et al. 2001). It is unclear as to what drives the expression of the smallest truncated sequence at $28.4 \mathrm{kDa}$ in the glucose medium, and the cell pellet and supernatant samples from this culture were not assayed for fatty acid ethyl ester production. 


\section{Biodiesel Assays}

Truncated CalB protein immobilized on Sepabead ${ }^{\circledR}$ EC-EP was capable of catalyzing the production of fatty acid alkyl esters from ratios of ethanol mixed with either corn oil or soybean oil samples, suggesting that truncation of the native CalB sequence has no adverse effect on transesterification catalytic activity. The primary constituents of pure corn and soybean oils are triacylglycerols with 16 and 18 carbonchain fatty acids, equating to $99.8 \%$ and $100 \%$ of their composition by weight, respectively (Ma and Hanna 1999). Therefore, biodiesel yield was measured by the total amount of C16 and C18 fatty acid ethyl esters detected by gas chromatography. The amount of $\mathrm{C} 18$ fatty acid ethyl esters was greater than the C16 fatty acid ethyl esters produced by the truncated CalB, ranging from 2.3-3.8 to 1 in ratio. It was expected that the amount of $\mathrm{C} 18$ ethyl esters would be greater, as fatty acid ethyl ester production is a direct function of the amount of fatty acid substrate oil present, which in this case was 7.5:1 $\mathrm{C} 18$ to $\mathrm{C} 16$. However, this decrease in ratio of $\mathrm{C} 18$ to $\mathrm{C} 16$ may be indicative of a preference towards smaller substrates by the truncated CalB enzyme when under conditions in which ethanol is present as the alcohol (Kato et al. 2007).

The resin containing the immobilized truncated CalB from the cell supernatant produced a combined yield of C16 and C18 ethyl esters per milligram of enzyme $3.4-4.5$-fold greater than the combined yield from the pelleted lysed cells in both the corn oil and soybean oil samples. The amount of CalB present in the supernatant samples was considerably lower than the pelleted samples, suggesting that enzyme in the more dilute supernatant has a higher affinity for coupling to the resin. This could possibly be 
due to fewer inhibiting factors, such as contaminating proteins originating from the yeast cells that could potentially interact with the substrate solution, or compete with the truncated CalB protein in coupling to the resin.

The total yield of $\mathrm{C} 16$ and $\mathrm{C} 18$ ethyl esters produced from the corn oil produced by the resin-bound truncated CalB, combining both the supernatant and pellet samples, was $36 \%$ higher than the commercially available lipase catalyzed production. Additionally, the truncated CalB enzyme produced 50\% more total ethyl esters than the commercially available lipase resin with soybean oil. When comparing the total amount of fatty acid ethyl esters produced from both the truncated CalB and commercially available lipase, the yield of $\mathrm{C} 16$ and $\mathrm{C} 18$ ethyl esters were greater from corn oil than from the soybean oil. This could be a result of the greater purity of the soybean oil, as the sample obtained for this study was commercial grade, versus the crude corn oil sample. Previous studies have shown that purity of the oil affects biodiesel production catalyzed by Candida antarctica lipase (Watanabe et al. 2002).

When the addition of an ionic catalytic resin was incorporated into the fatty acid ethyl ester production with the resin-bound truncated CalB cultured from rich medium, there was an increase by 53\% of $\mathrm{C} 16$ and $\mathrm{C} 18$ ethyl esters per milligram enzyme produced from corn oil when the ionic catalytic resin step preceded the resin-bound truncated lipase than when it followed it. It is possible the ionic resin may have functioned to remove some potentially inhibiting materials in the crude corn oil. Trials run for truncated CalB cultured from selective medium showed little effect on ethyl ester yield with the addition of an ionic catalytic resin whether prior or subsequent to the resin- 
bound lipase. A rich medium more closely resembles what is typical for yeast cell cultures in an industrial biodiesel production setting, and it is possible that it allowed for more growth of nonspecific yeast cells, lacking the truncated CalB protein sequence.

In the prior studies, all ethanol to oil substrate ratios were 15:1 (v/v), which has been reported in previous studies (Noureddini et al. 2005, Sanli and Canakci 2008) to be an optimal ratio for long-chain fatty acid ethyl ester production catalyzed by lipases. Therefore, it was of interest to test other ratios of the corn oil and ethanol to determine what effect there would be on fatty acid ethyl ester production catalyzed by the resinbound truncated CalB. A 5:1 (v/v) and 30:1 (v/v) ratio of ethanol to corn oil were employed alongside the 15:1 (v/v) ratio. The 5:1 ratio yielded the highest production of fatty acid ethyl esters, 3.7-fold higher than the ratio of 15:1 ethanol to corn oil, and 8.4-fold higher than the ratio 30:1 ethanol to corn oil. The lower substrate oil concentration and resulting higher availability of alcohol did not appear to limit the catalyzed transesterification reaction. If alcohol concentration is too high it has been shown to have negative implications on lipase catalyzed reactions such as inactivating the CalB enzyme irreversibly, even if immobilized (Shimada et al. 2002).

The resin-bound truncated CalB produced 56\% more butyl esters per milligram enzyme in 5:1 butanol to corn oil compared to the amount of ethyl ester produced in 5:1 ethanol to corn oil. The ratio of $\mathrm{C} 18$ to $\mathrm{C} 16$ fatty acid esters produced was higher for butanol (2.9 to 1 ) than for ethanol (1.8 to 1), suggesting that the enzyme has less of a preference for the $\mathrm{C} 16$ substrate when butanol is the alcohol. A 5:1 ratio of alcohol to 
fatty acid oil substrate was utilized initially after the previous study (Figure 10) showed this ratio to have the highest yield of fatty acid esters.

\section{Purification and Isolation of Truncated CalB}

The purified fraction identified as having the greatest amount of protein, presumed to be the truncated CalB, presented various bands on both the Coomassie stained gel and the Western blot following SDS-PAGE analysis. A band at approximately $50 \mathrm{kDa}$ was most notably present in the Coomassie stained gel among the purified fraction samples than any other band. However, in the Western blot analysis only a single band was noticeable at approximately $33 \mathrm{kDa}$ in the crude extract, cell supernatant, and cell pellet samples, most prominently in the latter. This suggests that the truncated CalB protein had not been efficiently extracted from the cell pellet, with too little available in the supernatant to be purified and isolated. The prominent protein band at $50 \mathrm{kDa}$ visible in the purified fractions of the Coomassie stained gel suggested the slight possibility of being a dimer of two truncated CalB proteins, since the size of the truncated sequence excluding the artificial ATG start codon, 29 attB, and 6 histidine tag from the original PCR assembly is approximately $30 \mathrm{kDa}$.

To assess the possibility of the protein band present at $50 \mathrm{kDa}$ on the Coomassie stain of the purified protein fractions representing a disulfide dimer of two truncated CalB proteins, the reducing agent $\beta$-mercaptoethanol (BME) was added to a $2 \mathrm{X}$ SDSPAGE loading buffer of the prepared samples. In the previous samples (Figures 14, 15), the $4 \mathrm{X}$ SDS- PAGE loading buffer used already contained the reducing agent dithiothreitol (DTT). It was of interest to compare the use of two different reducing 
agents. On the resulting Coomassie stained gel, the samples containing BME retained the protein band visible at $50 \mathrm{kDa}$ with no additional protein bands newly visible. If a protein band had appeared around 25-30 kDa, the approximate size of the truncated CalB sequence, with and without additional amino acid residues on the amino terminus, it would have been concluded that the band present at $50 \mathrm{kDa}$ very likely is a dimer of the truncated CalB protein. Although no band was present at $50 \mathrm{kDa}$ on the Western blot analysis of the purified protein fractions (Figure 10), the presence of a dimer is still possible as the 6-His tag on the amino terminus could be obstructed by the quaternary structure of the protein and inaccessible to the anti-His tag antibody.

Various detergents were used to extract the truncated CalB protein out of the cell pellet, which was confirmed by Western blot analysis to contain the majority of the recombinant protein after cell lysis. The detergent NP-40 appeared to have no effect on the Coomassie stained gel obtained after mixing the cell pellet in a $1 \%$ solution of the detergent with a Dounce homogenizer, in comparison to the initial Coomassie stained gel obtained. The NP-40 solution was increased to $10 \%$, but no change was present in the resulting Coomassie stained gel. Of significance was the presence of several, nonspecific protein bands in both Coomassie stained gels following the use of the NP-40 detergent, suggesting that the detergent was having an interaction with the chemical agents used for protein detection, therefore the decision to forego obtaining a Western blot was made in favor of proceeding with the testing of other detergents. The detergents Triton X-100 (10\%) and octyl- $\beta$-D-glucopyranoside (OGP, $1 \%)$ were tested concurrently and the resulting Western blots obtained showed faint protein bands at $33 \mathrm{kDa}$ in the cell supernatant samples following Dounce homogenization with each of the detergents. 
However, highly visible protein bands on the Western blot were still present in the cell pellet samples after mixing with the detergents, showing almost no change in appearance compared to the cell pellet samples prior to mixing with detergent. In addition to the truncated CalB enzyme, a full-length version of the CalB protein (Hughes et al. 2011) was assessed alongside for comparison of each the detergent samples to rule out any possibility of underlying aberrations in the truncated CalB protein sequence as a cause of preventing it from solubilizing in the cell supernatant.

Since extraction of the truncated CalB enzyme was unsuccessful using various detergents, the cell lysis step was reassessed and adjustments were made to the protocol involving the French Press apparatus. It was noted after consulting the European Molecular Biology Laboratory database that homogenizers must be operated at relatively higher pressures for yeast cells. By doubling the internal cell pressure from 15,000 psi to $30,000 \mathrm{psi}$, the cell supernatant obtained from the lysate appeared to have a prominently visible band on the Western blot analysis at $33 \mathrm{kDa}$. Additionally, there was no visible protein band at $33 \mathrm{kDa}$ in the cell pellet sample, which up until this point had been a fixture in each Western blot analysis. In the purified protein fractions, the samples that contained the highest concentration of protein according to the BioRad assay had a prominent protein band at $33 \mathrm{kDa}$, which had previously not been observed in these samples. There were three other additional protein bands present in the purified fraction samples at $80 \mathrm{kDa}, 55 \mathrm{kDa}$, and $15 \mathrm{kDa}$. The identity of these protein bands can only be speculated, but there is a possibility the bands present at $55 \mathrm{kDa}$ and $80 \mathrm{kDa}$ could indicate presence of a dimer and trimer of the truncated CalB protein, respectively. It has been determined in previous studies that native CalB enzyme forms closely packed 
dimeric oligomer structures (Uppenberg et al. 1995). Studies have also shown that adding small protein sequences to the $\mathrm{N}$-terminus of the native CalB sequence affects the formation of these dimers, impacting enzyme activity to various degrees in relation to how much the active site is altered (Seo et al. 2009). There could be some indications of this phenomenon with the addition of the 29 attB and 6 His-tag amino acids to the truncated CalB sequence.

\section{Kinetic Activity of Truncated CalB}

To study the kinetic properties of the truncated CalB, assays measuring the initial rate of the enzyme with the substrate para-nitrophenyl butyrate (p-NPB) were performed. This was an ideal substrate as it is a water soluble compound capable of undergoing transesterification when an alcohol is present, yielding the product para-nitrophenol which has a distinct yellow hue detectable by UV/Vis spectrophotometry at 400-405 nm. Several studies have previously employed this substrate in kinetic enzyme assays, specifically with Candida antarctica lipase B, and two were adapted in this research to measure the kinetic activity of the truncated CalB enzyme. The first method (Blank et al. 2006) used for this study showed the rate of catalysis, $V_{0}$, rising linearly with the increase in concentration of the substrate p-NPB initially with no indication of leveling off and reaching a maximal rate, $\mathrm{V}_{\max }$, at the highest tested $\mathrm{p}-\mathrm{NPB}$ concentration of $1000 \mu \mathrm{M}$. Additional concentrations of substrate were measured, up to $6000 \mu \mathrm{M}$, and indicated a leveling off of the $\mathrm{V}_{0}$ values. The kinetic constants $\mathrm{V}_{\max }$ and $\mathrm{K}_{\mathrm{m}}$ were determined by using least squares non-linear regression to fit the data to the Michaelis-Menten equation 
(Figure 23). The theoretical data converged closely with the experimental measurements, and both the $\mathrm{V}_{\max }$ and $\mathrm{K}_{\mathrm{m}}$ values were within reasonable limits of the data measured.

The second method utilized (Martinelle et al. 1995) again employed p-NPB as the substrate, but it included slight changes in the buffer solution used and the addition of a sonicator bath. The substrate concentration range was also increased up to $20000 \mu \mathrm{M}$. The measured and calculated $\mathrm{V}_{0}$ values for the truncated CalB increased as concentration of the substrate p-NPB increased, initially giving a linear plot, but eventually started to level out with clear visual indication that $\mathrm{V}_{\max }$ had been reached. Non-linear regression of least squares closely fit the data to the Michaelis-Menten equation (Figure 24), calculating $\mathrm{V}_{\max }$ and $\mathrm{K}_{\mathrm{m}}$ values within reasonable limits of the data measured. Compared to the kinetic constants calculated for truncated CalB activity when using the method of Blank et al. (Table 1), the $\mathrm{V}_{\max }$ value was higher for the enzyme when using the method of Martinelle et al. $\left(0.274 \mu \mathrm{mol} \mathrm{mg}{ }^{-1} \mathrm{~min}^{-1}\right.$ versus $\left.0.0151 \mu \mathrm{mol} \mathrm{mg}^{-1} \mathrm{~min}^{-1}\right)$. Additionally, the concentration of truncated CalB enzyme used in the former method was $62.5 \%$ greater than the latter method $(0.32 \mu \mathrm{g} / \mu \mathrm{L}$ versus $0.12 \mu \mathrm{g} / \mu \mathrm{L})$, indicating that less enzyme was required for catalysis of the conversion of para-nitrophenyl butyrate to paranitrophenol.

The full-length CalB was analyzed for comparison using the method of Martinelle et al., producing similar results to the truncated CalB. Non-linear regression of least squares closely fit the data to the Michaelis-Menten equation (Figure 25), calculating $\mathrm{V}_{\max }$ and $\mathrm{K}_{\mathrm{m}}$ values within reasonable limits of the data measured. A comparison of the truncated and full-length CalB kinetic constants (Table 1) showed that the kinetic 
constants for the truncated CalB and full-length enzyme were comparable, with the fulllength having a slightly higher $\mathrm{K}_{\mathrm{m}}$ value, $287 \mu \mathrm{M}$ versus $258 \mu \mathrm{M}$, and very slightly lower $\mathrm{V}_{\max }$ value $\left(0.267 \mu \mathrm{mol} \mathrm{mg}^{-1} \mathrm{~min}^{-1}\right.$ versus $\left.0.274 \mu \mathrm{mol} \mathrm{mg}^{-1} \mathrm{~min}^{-1}\right)$. However, the concentration of the full-length CalB was $75 \%$ less than the truncated CalB protein concentration $(0.030 \mu \mathrm{M}$ versus $0.12 \mu \mathrm{M})$, therefore less enzyme was required to catalyze the reaction at the same rate as the highest amount of truncated CalB able to be extracted from yeast cells.

In conclusion, the truncated CalB was determined to be not be as active as the full-length native protein, but still proved to be catalytically viable and capable of producing measurable amounts of fatty acid alkyl esters useful in biodiesel production. It was also determined that an active modified CalB was expressed in the S. cerevisiae yeast strain PJ69-4 which could be a valuable asset in future industrial applications employing yeast capable of producing cellulosic ethanol in large-scale enzymatic biodiesel production.

\section{Future Work}

There is still much need in the industrial world for recombinant DNA and genetic engineering technologies. Modification of existing known enzymes with current industrial purpose is a relatively easy process that can lead to potentially cost-effective results. Alteration and manipulation of specific nucleic acids or entire amino acid sequences could produce improved catalytic abilities of an enzyme.

While corn is still one of the easiest and least expensive sources of ethanol production, there are potentially better alternatives being developed. Cellulosic biomass, 
such as the non-edible portions of food crops, grasses, and algae, is a prime candidate since it requires a fraction of the input resources, greatly reducing expense (Hughes et al. 2009). Additionally, cellulosic biomass is a source of galactose, which is necessary in order to activate the Gall promoter responsible for driving the expression of the lipase enzyme. The need of adding galactose into the ethanol biorefinery is thus eliminated, which reduces production costs and time. Already having the truncated CalB expressed in yeast capable of producing ethanol, the incorporation of cellulosic biomass as the fatty acid substrate could potentially be a relatively simple, independent system for producing biodiesel.

Another potential industrial use for lipase enzymes is polymer production. The main byproduct of the transesterification reaction is glycerol, which is a potential precursor molecule for polymers. Studies have shown that Candida antarctica lipase B is an effective catalyst for polymerization, and is quickly gaining attention in the polymer production industry for being cost-effective and a more environmentally friendly alternative than the currently used chemical catalysts. (Pessagno and Baldessari 2000). The concept of integrating the polymer and biodiesel processes is a relatively new one and is a potentially rich area of research in the foreseeable future. 


\section{REFERENCES}

Akoh, C. C., Chang, S. W., Lee, G. C., Shaw, J. F. 2007. Enzymatic approach to biodiesel production. Journal of Agricultural and Food Chemistry. 55: 89959005 .

Al-Zuhair, S. 2005. Production of biodiesel by lipase-catalyzed transesterification of vegetable oils: a kinetics study. Biotechnology Progress. 21: 1442-1448.

Blank, K., Morfill, J., Gumpp, H., Gaub, H. 2006. Functional expression of Candida antarctica lipase B in Escherichia coli. Journal of Biotechnology. 125: 474483.

Bradford, M. M. 1976. A rapid and sensitive method for the quantization of microgram quantities of protein utilizing the principle of protein-dye binding. Analytical Biochemistry. 72: 248.

Branden, C., Tooze, J. 1999. Introduction to Protein Structure ( $2^{\text {nd }}$ edition). New York, NY: Garland Publishing Inc.

Fukuda, H., Kondo, A., Noda, H. 2001. Biodiesel fuel production by transesterification of oils. Journal of Bioscience and Bioengineering. 92: 405-416.

Gotor-Fernandez, V., Busto, E., Gotor, V. 2006. Candida antarctica lipase B: an ideal biocatalyst for the preparation of nitrogenated organic compounds. Advanced Synthesis and Catalysis. 348: 797-812.

Hughes, S. R., Hector, R. E., Rich, J. O., Qureshi, N., Bischoff, K. M., Dien, B. S., Saha, B. C., Liu, S., Cox, E. J., Jackson, J. S., Sterner, D. E., Butt, T. R., LaBaer, J., Cotta., M. A. 2009. Automated yeast mating protocol using open reading frames from Saccharomyces cerevisiae genome to improve yeast strains for cellulosic ethanol production. Journal of Laboratory Automation. 14: 190-199.

Hughes, S., Moser, B., Harmsen, A., Bischoff, K., Jones, M., Pinkelman, R., Bang, S., Tasaki, K., Doll, K., Qureshi, N., Saha, B., Liu, S., Jackson, J., Robinson, S., Cotta, M., Rich, J., and Caimi, P. 2011. Production of Candida antarctica lipase B gene open reading frame using automated PCR assembly protocol on robotic workcell and expression in an ethanologenic yeast for use as a resinbound biocatalyst in biodiesel production. Journal of Laboratory Automation. 16: $17-37$. 
Kato, M., Fuchimoto, J., Tanino, T., Kondo, A., Fukuda, H., Ueda, M. 2007. Preparation of a whole-cell biocatalyst of mutated Candida antarctica lipase (mCALB) by a yeast molecular display system and its practical properties. Applied Microbiology and Biotechnology. 75: 549-555.

Kramer, D. M., Lehmann, K., Pennewiss, H., Plainer, H. 1979. Oxirane acrylic beads for protein immobilization: a novel matrix for biocatalysis and biospecific adsorption. $26^{\text {th }}$ International IUPAC Symposium on Macromolecules. Mainz, Germany, September 17-21.

Ma, F., Hanna, M. A. 1999 Biodiesel production: a review. Bioresource Technology. 70: $1-15$.

Martinelle, M., Holmquist, M., Hult, K. 1995. On the interfacial activation of Candida antarctica lipase A and B as compared with Humicola lanuginose lipase. Biochemica et Biophysica Acta. 1258: 272-276.

Mateo, C., Fernández-Lorente, G., Abian, O., Fernández-Lafuente, R., Guisán, J. M. 2000. Multifunctional epoxy supports: a new tool to improve the covalent immobilization of proteins. The promotion of physical adsorptions of proteins on the supports before their covalent linkage. Biomacromolecules. 1: 739-745.

Mateo, C., Abian, O., Fernández-Lorente, G., Pedroche, J., Fernández-Lafuente, R., Guisán, J. M. 2002. Epoxy Sepabeads: a novel epoxy support for stabilization of industrial enzymes via very intense multipoint covalent attachment. Biotechnology Progress. 18: 629-634.

Noureddini, H., Gao, X., Philkana, R. S. 2005. Immobilized Pseudomonas cepacia lipase for biodiesel fuel production from soybean oil. Bioresource Technology. 96: $769-777$.

Overbeeke, P. L. A., Govardhan, C., Khalaf, N., Jongejan, J.A., Heijnen, J.J. 2000. Influence of lid conformation on lipase enantioselectivity. Journal of Molecular Catalysis B: Enzymatic. 10: 385-393.

Pessagno, R. C., Baldessari, A. 2000. Lipase-catalyzed polymerization of glycerol and dicarboxylic acids in an organic medium. Molecules. 5: 372-373. doi: $10.3390 / 50300372$

Pessela, B. C. C., Mateo, C., Carrascosa, A. V., Vian, A., García, J. L., Rivas, G., Alfonso, C., Guisán, J. M., Fernández-Lafuente, R. 2003. One-step purification, covalent immobilization, and additional stabilization of a thermophilic poly-Histagged $\beta$-galactosidase from Thermus $s p$. strain T2 by using novel heterofunctional chelate-epoxy Sepabeads. Biomacromolecules. 4: 107-113. 
Rotticci, D., Norin, T., Hult, K., Martinelle, M. 2000. An active-site titration method for lipases. Biochemica et Biophysica Acta. 1483: 132-140.

Sanli, H., Canakci, M. 2008. Effects of different alcohol and catalyst usage on biodiesel production from different vegetable oils. Energy \& Fuels. 22: 2713-2719.

Seo, H. S., Kim, S. E., Han, K. Y., Park, J. S., Kim, Y. H., Sim, S. J., Lee, J. 2009. Functional fusion mutant of Candida antarctica lipase B (CalB) expressed in Escherichia coli. Biochemica et Biophysica Acta. 1794: 519-525.

Shimada, Y., Watanabe, Y., Sugihara, A., Tominaga, Y. 2002. Enzymatic alcoholysis for biodiesel fuel production and application of the reaction to oil processing. Journal of Molecular Catalysis B: Enzymatic. 17: 133-142.

Silvia, N., Roberto, V., Moreno, D. 2006. Purification of commercial lipases by hydrophobic interaction chromatography using Sepabeads® resins. http://resindion.com

Thompson, S. R., Gulyas, K. D., Sarnow, P. 2001. Internal initiation in Saccharomyces cerevisiae mediated by an initiator $\mathrm{tRNA} / \mathrm{eIF} 2$-independent internal ribosome entry site element. Proceedings of the National Academy of Sciences. 98: 12972-12977.

Uppenberg, J., Patker, S., Bergpors, T., Jones, T. A. 1994a. Crystallization and preliminary x-ray studies of lipase B from Candida antarctica. Journal of Molecular Biology. 235: 790-792.

Uppenberg, J., Hansen, M. T., Patkar, S., Jones, T. A. 1994b. The sequence, crystal structure determination and refinement of two crystal forms of lipase B from Candida antarctica. Structure. 2: 293-308.

Uppenberg, J., Ohrner, N., Norin, M., Hult, K., Kleywegt, G., Patkar, S., Waagen, V., Anthonsen, T., Jones, T. A. 1995. Crystallographic and molecular-modeling studies of lipase B from Candida antarctica reveal a stereospecificity pocket for secondary alcohols. Biochemistry. 34: 16838-16851.

Villeneuve, P., Muderhwa, J. M., Graille, J., Haas, H. J. 2000. Customizing lipases for biocatalysis: a survey of chemical, physical and molecular biological approaches. Journal of Molecular Catalysis B: Enzymatic. 9: 113-148.

Watanabe, Y., Shimada, Y., Sugihara, A., Tominaga, Y. 2002. Conversion of degummed soybean oil to biodiesel fuel with immobilized Candida antarctica lipase. Journal of Molecular Catalysis B: Enzymatic. 17: 151-155. 


\section{APPENDIX A \\ PROTEIN SOLUBILIZING DETERGENTS}

The following detergent solutions were prepared in $50 \mathrm{mM}$ Tris, $100 \mathrm{mM} \mathrm{NaCl}$, pH 7.5 buffer.

\begin{tabular}{lrrr}
\hline \hline Detergent & Percentage & Detergent Vol. & Buffer Vol. \\
\hline Nonidet P-40 & $\leq 1 \%$ & $0.2 \mathrm{~mL}$ & $20 \mathrm{~mL}$ \\
& $10 \%$ & $2 \mathrm{~mL}$ & $18 \mathrm{~mL}$ \\
Triton X-100 & $10 \%$ & $2 \mathrm{~mL}$ & $18 \mathrm{~mL}$ \\
n-octyl glucopyranoside & $\leq 1 \%$ & $* 0.2 \mathrm{~g}$ & $20 \mathrm{~mL}$ \\
\hline *detergent in solid form, therefore measured in units of weight &
\end{tabular}

The prepared detergent solution was added to the $50 \mathrm{~mL}$ centrifuge tube containing the cell pellet, and then transferred to a glass mortar fitted to a Douncer pestle. 


\section{APPENDIX B}

\section{BRADFORD PROTEIN ASSAY}

The following standard curve was set up using a prepared BSA $1 \mathrm{mg} / \mathrm{mL}$ standard diluted to $0.1 \mathrm{mg} / \mathrm{mL}$ using Nanopure water in $1.5 \mathrm{~mL}$ microcentrifuge tubes. Samples were evaluated by UV/Vis spectrophotometry, measuring absorbance at $595 \mathrm{~nm}$ in $1.5 \mathrm{~mL}$ polystyrene cuvettes. Sample 1 is used for a blank.

\begin{tabular}{c|c|c|c|c|c}
\hline \hline Sample & $0.1 \mathrm{mg} / \mathrm{mL}$ BSA & $\mathrm{H}_{2} \mathrm{O}$ & Bio-Rad Reagent® & Protein $(\mu \mathrm{g})$ & Abs 595 nm \\
\hline \hline 1 & $0 \mu \mathrm{L}$ & $800 \mu \mathrm{L}$ & $200 \mu \mathrm{L}$ & 0 & 0.000 \\
2 & $20 \mu \mathrm{L}$ & $780 \mu \mathrm{L}$ & $200 \mu \mathrm{L}$ & 2 & 0.068 \\
3 & $40 \mu \mathrm{L}$ & $760 \mu \mathrm{L}$ & $200 \mu \mathrm{L}$ & 4 & 0.168 \\
4 & $80 \mu \mathrm{L}$ & $720 \mu \mathrm{L}$ & $200 \mu \mathrm{L}$ & 8 & 0.401 \\
5 & $120 \mu \mathrm{L}$ & $680 \mu \mathrm{L}$ & $200 \mu \mathrm{L}$ & 12 & 0.548 \\
6 & $160 \mu \mathrm{L}$ & $640 \mu \mathrm{L}$ & $200 \mu \mathrm{L}$ & 16 & 0.681 \\
7 & $200 \mu \mathrm{L}$ & $600 \mu \mathrm{L}$ & $200 \mu \mathrm{L}$ & 20 & 0.833 \\
\hline \hline
\end{tabular}

A plot of absorbance at $595 \mathrm{~nm}$ versus protein $(\mu \mathrm{g})$ was constructed in Microsoft ${ }^{\circledR}$ Excel. A linear regression analysis was performed to determine the equation of the line of best 
fit. The unknown protein samples, as well as the samples of crude extract, cell supernatant, and the IMAC buffer eluates were diluted by an amount that produced a visual color between $2-10 \mu \mathrm{g}$ of protein. Each sample was analyzed by UV/Vis spectrophotometry to determine absorbance at $595 \mathrm{~nm}$. Using the equation of the standard curve, the amount of protein per volume of sample used can be calculated. 


\section{APPENDIX C}

\section{BIODIESEL ASSAYS}

A series of assays designed to mimic a potential industrial process for producing biodiesel with a system of columns packed with lipase enzymes immobilized on specialty resins is shown below.

\begin{tabular}{|c|c|c|c|c|}
\hline & Lipase Catalyst & Oil & Alcohol & Ratio (v/v) \\
\hline \multirow[t]{6}{*}{$\overline{\text { Assay } 1}$} & tCalB (Pel) & Com & Ethanol & $15: 1$ \\
\hline & $\mathrm{tCalB}(\mathrm{Pel})$ & Soybean & Ethanol & $15: 1$ \\
\hline & tCalB (Sup) & Com & Ethanol & $15: 1$ \\
\hline & tCalB (Sup) & Soybean & Ethanol & $15: 1$ \\
\hline & Novozym 435 & Com & Ethanol & $15: 1$ \\
\hline & Novozym 435 & Soybean & Ethanol & $15: 1$ \\
\hline \multirow[t]{4}{*}{ Assay 2} & $\mathrm{tCalB}(\mathrm{Sup})^{\mathrm{a}, \mathrm{b}}$ & Com & Ethanol & $15: 1$ \\
\hline & $\mathrm{tCalB}(\mathrm{Sup})^{\mathrm{a}, \mathrm{c}}$ & Com & Ethanol & $15: 1$ \\
\hline & $\mathrm{tCalB}(\mathrm{Sup})^{\mathrm{b}}$ & Corm & Ethanol & $15: 1$ \\
\hline & $\mathrm{tCalB}(\mathrm{Sup})^{\mathrm{c}}$ & Com & Ethanol & $15: 1$ \\
\hline \multirow[t]{6}{*}{ Assay 3} & $\mathrm{tCalB}(\mathrm{Sup})^{\mathrm{b}}$ & Com & Ethanol & $5: 1$ \\
\hline & $\mathrm{tCalB}(\mathrm{Sup})^{\mathrm{c}}$ & Com & Ethanol & $5: 1$ \\
\hline & $\mathrm{tCalB}(\mathrm{Sup})^{\mathrm{b}}$ & Corm & Ethanol & $15: 1$ \\
\hline & $\mathrm{tCalB}(\operatorname{Sup})^{\mathrm{C}}$ & Corm & Ethanol & $15: 1$ \\
\hline & $\mathrm{tCalB}(\mathrm{Sup})^{\mathrm{b}}$ & Com & Ethanol & $30: 1$ \\
\hline & $\mathrm{tCalB}(\operatorname{Sup})^{\mathrm{c}}$ & Corn & Ethanol & $30: 1$ \\
\hline \multirow[t]{2}{*}{ Assay 4} & tCalB (Sup) & Corm & Ethanol & $5: 1$ \\
\hline & tCalB (Sup) & Com & n-Butanol & $5: 1$ \\
\hline
\end{tabular}

${ }^{3}$ Truncated CalB protein extract from yeast cells grown in CM Gal -Ura

${ }^{b} \mathrm{Alcohol}$ and oil mixture passed through DIAION ${ }^{\mathrm{B}}$ ionic resin prior to resin-bound truncated CalB

${ }^{c} \mathrm{Alcohol}$ and oil mixture passed through DIAION ionic resin following the resin-bound truncated CalB 


\section{APPENDEX D \\ KINETIC ENZYME ASSAYS}

Using the method of Blank et al. (2006), a $20 \mathrm{mM}$ stock solution of the substrate p-NPB was prepared with $3.5 \mu \mathrm{L}$ p-NPB in $1 \mathrm{~mL}$ ethanol (EtOH). Various substrate solutions were prepared using the $20 \mathrm{mM}$ stock solution and ethanol for a total volume of $25 \mu \mathrm{L}$.

\begin{tabular}{ccc}
\hline \hline p-NPB] mM & $\begin{array}{r}\text { Vol. } 20 \mathrm{mM} \text { p-NPB } \\
\text { in EtOH } \mu \mathrm{L}\end{array}$ & Vol. EtOH $\mu \mathrm{L}$ \\
\hline 0.04 & 1.00 & 24.0 \\
0.08 & 2.00 & 23.0 \\
0.12 & 3.00 & 22.0 \\
0.20 & 5.00 & 20.0 \\
0.32 & 8.00 & 17.0 \\
0.40 & 10.0 & 15.0 \\
0.60 & 15.0 & 10.0 \\
0.72 & 18.0 & 7.00 \\
0.80 & 20.0 & 5.00 \\
1.00 & 25.0 & 0.00 \\
\hline \hline
\end{tabular}


A total reaction volume of $500 \mu \mathrm{L}$ was measured in a polystyrene cuvette; $470 \mu \mathrm{L}$ of 50 $\mathrm{mM}$ sodium phosphate, $150 \mathrm{mM} \mathrm{NaCl}, \mathrm{pH} 7.0,0.5 \%$ (v/v) Triton X-100, 5\% (v/v) ethanol buffer; $25 \mu \mathrm{L}$ prepared substrate solution; $5 \mu \mathrm{L}$ truncated CalB.

Using the method of Martinelle et al. (1995), a total reaction volume of $1000 \mu \mathrm{L}$ was measured in a quartz cuvette; $990 \mu \mathrm{L}$ including $50 \mathrm{mM}$ MOPS, $\mathrm{pH} 7.5,1 \%(\mathrm{v} / \mathrm{v})$ acetonitrile buffer and p-NPB substrate, placed under sonication for 2 minutes; $10 \mu \mathrm{L}$ truncated CalB or full-length CalB were added to initiate the reaction rate.

\begin{tabular}{ccc}
\hline \hline p-NPB $] \mathrm{mM}$ & Vol. p-NPB $\mu \mathrm{L}$ & Vol. Buffer $\mu \mathrm{L}$ \\
\hline 0.04 & $* 0.50$ & 980 \\
0.08 & $* 1.00$ & 979 \\
0.10 & $* 1.25$ & 979 \\
0.20 & 0.04 & 980 \\
0.40 & 0.07 & 980 \\
2.0 & 0.35 & 980 \\
6.0 & 1.05 & 979 \\
8.0 & 1.41 & 979 \\
10.0 & 1.76 & 978 \\
12.0 & 2.11 & 978 \\
20.0 & 3.52 & 977 \\
\hline *Volume $80 \mathrm{mM}$ p-NPB in $\mathrm{CH}_{3} \mathrm{CN}$ & \\
\hline
\end{tabular}

